\title{
Review and classification of indicators of green water availability and scarcity
}

\author{
J. F. Schyns, A. Y. Hoekstra, and M. J. Booij \\ Twente Water Centre, University of Twente, Enschede, the Netherlands \\ Correspondence to: J. F. Schyns (j.f.schyns@utwente.nl)
}

Received: 20 May 2015 - Published in Hydrol. Earth Syst. Sci. Discuss.: 11 June 2015

Revised: 4 November 2015 - Accepted: 5 November 2015 - Published: 18 November 2015

\begin{abstract}
Research on water scarcity has mainly focussed on blue water (ground- and surface water), but green water (soil moisture returning to the atmosphere through evaporation) is also scarce, because its availability is limited and there are competing demands for green water. Crop production, grazing lands, forestry and terrestrial ecosystems are all sustained by green water. The implicit distribution or explicit allocation of limited green water resources over competitive demands determines which economic and environmental goods and services will be produced and may affect food security and nature conservation. We need to better understand green water scarcity to be able to measure, model, predict and handle it. This paper reviews and classifies around 80 indicators of green water availability and scarcity, and discusses the way forward to develop operational green water scarcity indicators that can broaden the scope of water scarcity assessments.
\end{abstract}

\section{Introduction}

Freshwater is a renewable resource that is naturally replenished over time when moving through the hydrological cycle (Oki and Kanae, 2006; Hoekstra, 2013). Precipitation forms the input of freshwater on land. Subsequently, it takes the blue or the green pathway back to the ocean and atmosphere before eventually returning as precipitation again (Falkenmark, 2003; Falkenmark and Rockström, 2006, 2010). The water that runs off to the ocean via rivers and groundwater is called the blue water flow. The green water flow is formed by the water that is temporarily stored in the soil and on top of vegetation and returns to the atmosphere as evaporation instead of running off (Hoekstra et al., 2011). As suggested by Savenije (2004), in this paper we use the term evaporation (instead of the often used term evapotranspiration) to refer to the vapour flux from land to atmosphere, which includes soil evaporation, evaporation of intercepted water, transpiration and in some cases (e.g. rice or swamp vegetation) openwater evaporation. About three-fifth of the precipitation over land takes the green path and two-fifth the blue path (Oki and Kanae, 2006).

Both blue and green water flows are made productive for human purposes. Blue water is used for industrial and domestic purposes and irrigation in agriculture. Green water sustains crop production, grazing lands, forestry and terrestrial ecosystems (Rockström, 1999; Rockström et al., 1999; Savenije, 2000; Gerten et al., 2005). These systems provide food, fibres, biofuels, timber and livestock products and other ecosystem services humans benefit from (Millennium Ecosystem Assessment, 2005; Gordon et al., 2010).

Although freshwater is renewable, this does not mean that its availability is unlimited. In fact, freshwater is also a finite resource (Hoekstra, 2013). Over a certain period, there falls a certain amount of precipitation. This limits both blue and green water availability in time. Human society cannot appropriate more water than is available. The finiteness of freshwater, in combination with the various competing demands for water, makes water a scarce resource.

Water scarcity is becoming increasingly important for multiple reasons. The growing world population leads to rising demands for food, energy and other waterconsuming goods and services (Hejazi et al., 2014; WWAP, 2015). Moreover, people's diets are changing toward more livestock-based products, due to rising incomes and continuing urbanization (Molden, 2007). Such diets are more water and land intensive (Erb et al., 2009; Kastner et al., 2012; Odegard and van der Voet, 2014). Policies towards more en- 
ergy production from biomass create additional pressure on water and land (Hejazi et al., 2014). Additionally, a changing climate with increased variability and more extremes (IPCC, 2013) amplifies water scarcity (WWAP, 2014).

Given that green and blue water resources are limited and there are competing demands for both, green water as well as blue water are scarce. Therefore, it is surprising that research and debate on water scarcity have been, and still are, mainly focussed on blue water (Vörösmarty et al., 2000, 2010; Rijsberman, 2006; Wada et al., 2011; Hoekstra et al., 2012; WWAP, 2014, 2015). Although the importance of green water has increasingly gained acceptance since Falkenmark (1995) drew attention to it in the mid-1990s (Savenije, 2000; Rockström, 2001; Rijsberman, 2006; Liu et al., 2009; Hanasaki et al., 2010; Hoekstra and Mekonnen, 2012), the notion of green water scarcity is addressed in the literature to a limited extent (Falkenmark et al., 2007; Falkenmark, 2013a, b). While the need to incorporate green water in water scarcity indicators and assessments has already been expressed since the beginning of this millennium (Savenije, 2000; Rockström, 2001; Rijsberman, 2006; Falkenmark and Rockström, 2006), only a few attempts have been made so far in the form of combined green-blue water scarcity assessments (Rockström et al., 2009; Gerten et al., 2011; Kummu et al., 2014) (discussed in detail in Sect. 3.2).

Green water scarcity refers to the competition over limited green water resources and allocation over competing demands. This allocation occurs mostly implicitly and indirectly, since generally it is land that is been allocated to a certain use. This indirectness of allocation, together with the absence of a price, makes green water scarcity invisible in our economy. This does not mean, though, that green water resources are not scarce, since using green water for one purpose makes it unavailable for another purpose. We need to measure how scarce green water is in order to answer questions like following: Can we produce enough food, feed, fibres, bioenergy and forestry products with limited availability of water resources and suitable land? How can we do so without compromising natural ecosystems and other sectors that put a claim on water and land resources? For studying these crucial questions, a sole assessment of blue water scarcity is insufficient.

Therefore, it is due time that more attention is given to green water scarcity and how we can measure it. In this review, we make an inventory of existing indicators of green water availability and scarcity, and classify them based on their scope and purpose of measurement. The classification allows us to discuss similarities and differences between indicators and give advice on how the various indicator classes could be used to measure different kinds of green water availability or scarcity. This is useful in order to properly include limitations in green water availability in water scarcity assessments.

A review of green water scarcity indicators is new in its kind. Past reviews of water scarcity indicators (Savenije,
2000; Rijsberman, 2006) date back a while and hence do not include recent developments in the field, especially those related to the inclusion of green water. There exist multiple reviews of indicators of aridity (Wallén, 1967; Walton, 1969; Stadler, 2005) and drought (World Meteorological Organization, 1975; Wilhite and Glantz, 1985; Maracchi, 2000; Tate and Gustard, 2000; Keyantash and Dracup, 2002; Heim, 2002; Hayes, 2007; Kallis, 2008; Mishra and Singh, 2010; Sivakumar et al., 2011). We classify and discuss these indicators in an overarching way. First, we discuss the multiple dimensions of water availability and scarcity, and sharpen the scope of this review (Sect. 2). Next, we classify and review green water availability and scarcity indicators (Sect. 3). Finally, we draw conclusions and discuss future research directions (Sect. 4).

\section{Multiple aspects of water availability and scarcity}

The concepts of water availability and scarcity are examined in Sect. 2.1 to 2.4. We will reflect on these concepts in broad terms, not yet focussing on green water. In Sect. 2.5, we detail the scope of the indicators discussed in this paper.

\subsection{Water availability and scarcity}

A straightforward definition of water scarcity is "an excess of water demand over available supply" (FAO, 2012). Various other definitions of water scarcity exist that aim to be more inclusive.

"An imbalance between supply and demand of freshwater in a specified domain (country, region, catchment, river basin, etc.) as a result of a high rate of demand compared with available supply, under prevailing institutional arrangements (including price) and infrastructural conditions." (FAO, 2015)

"When an individual does not have access to safe and affordable water to satisfy her or his needs for drinking, washing or their livelihoods we call that person water insecure. When a large number of people in an area are water insecure for a significant period of time, then we can call that area water scarce." (Rijsberman, 2006)

Considering these definitions, we can conclude that water scarcity is not something that is experienced by a single person at a particular moment (day or week). Rather, it is experienced by a larger community within a certain geographic area (e.g. catchment or country) and relates to larger timescales (months or years).

The concept of scarcity describes a relation between humans and nature (Baumgärtner et al., 2006). Nevertheless, we can distinguish water scarcity mainly caused by natural conditions of low water availability from scarcity mainly induced by a large human demand relative to natural availability. The latter can also occur in naturally water-abundant areas (Pereira et al., 2002). 
Until now we have spoken about physical water scarcity, referring to the situation where there is insufficient water to meet human demand. If human, institutional and financial capital limit access to water, the term economic water scarcity applies (Seckler et al., 1999; Molden, 2007). In a broader sense, Ohlsson (2000) defines social resource scarcity as the situation in which social resources required to successfully adapt to physical water scarcity fall short.

\subsection{Relative and absolute water scarcity}

According to economic theory, water is a scarce good because it carries opportunity costs, which are the benefits foregone from possible alternative uses of the water (FAO, 2004). This is a form of "relative scarcity" based on the assumption of substitutability of goods (Baumgärtner et al., 2006). Water can be scarce in the relative sense also in water-abundant areas, because allocating water to purpose A implies it cannot be allocated to purpose B. In other words, water for purpose $\mathrm{A}$ is scarce in relation to water for other purposes. In common language we are inclined to say that sometimes water is scarce and at other times it is not. In economic sense, water is always scarce; the degree of water scarcity can vary though, and it can even be zero if alternative uses and thus competition is absent.

We speak of "absolute scarcity" when according to Baumgärtner et al. (2006) "scarcity concerns a nonsubstitutable means for satisfaction of an elementary need and cannot be levied by additional production". This means that in an area with a limited amount of water resources (that cannot be increased), at a certain level of consumption, water for elementary purposes (e.g. drinking and food production) will no longer be substitutable with water used for less essential purposes. In this case, there is absolute scarcity of water. Whether water is scarce in the absolute or relative sense thus depends on the degree of water scarcity: relative water scarcity turns into absolute scarcity when the boundaries of water exploitation are approached.

\subsection{Blue and green water}

Freshwater essentially stems from precipitation, which partitions into green and blue water (Falkenmark and Rockström, 2006, 2010). As discussed in the introduction of this paper, water availability and scarcity can pertain to both blue or green water resources, separately or in combination (Falkenmark, 2013a).

In contrast to the clear definition of blue water, various definitions of green water exist, defining it as an inflow (precipitation), a stock (rainwater in the soil) or an outflow (evaporation of rainwater). Often, the term green water is used to refer to "rainwater stored in the soil" or more specifically plant-available soil moisture in the unsaturated zone (Falkenmark et al., 2007; Falkenmark, 2013a); in this context the term green water is interpreted as a stock. Commonly, the distinction is made between green water stock and green water flow (Falkenmark and Rockström, 2006, 2010). The latter is an outflow, usually defined as actual evaporation over land (referring to the entire land-atmosphere vapour flux; see comment in the introduction), but it has also been defined as transpiration only (Savenije, 2000). Furthermore, some authors include precipitation (i.e. an inflow) in the definition of green water (Weiskel et al., 2014). The latter is in contrast with the definition of Falkenmark and Rockström (2006) (adhered to in this paper) that precipitation is the undifferentiated freshwater resource. Scholars who have tried to quantify green water availability in water scarcity assessments defined it as the actual evaporation flux over land to the atmosphere (Rockström et al., 2009; Gerten et al., 2011; Kummu et al., 2014) (Sect. 3).

While not always made explicit in definitions, an accurate description of the green water storage and flow excludes the part of the storage and vapour flow that originates from blue water resources, which have been redirected to the soil moisture stock by means of irrigation, capillary rise or natural flooding (Hoekstra et al., 2011). In such cases, the green and blue contributions to the soil moisture can be tracked with a model-based water balance approach (see Chukalla et al., 2015).

\subsection{Water quantity and quality}

Water scarcity is not only a function of the quantity of the water resource in relation to the demand, but also the quality of the resource in relation to the required quality for its end purpose (Pereira et al., 2002). If there is sufficient water available for a certain purpose, but it is polluted to such an extent that it is not usable for that purpose, then water can be considered scarce as long as the means are not available for cleaning the water to a desirable level. Pollution of water resources can thus aggravate water scarcity (FAO, 2012).

Water quality in the case of green water differs from that of blue water. The quality of green water depends on soil properties such as nutrient availability, nutrient retention capacity and the presence of salts and toxic substances. However, close ties with blue water quality do exist. For example, blue water used for irrigation can increase soil salinity when the water is brackish or saline and it can also flush out excess nutrients and other substances.

\subsection{Scope of the review and classification}

This paper focuses on green water, water quantity and physical water scarcity and treats of both green water availability and scarcity. In the next section, we consider indicators within this scope, including indicators of aridity, agricultural, meteorological and vegetation drought, soil moisture availability and overall green-blue water scarcity. The focus of this paper implies that several concepts and indicators fall outside the scope of the classification. The concepts and in- 
dicators focussing on blue water that are outside the scope of this paper are the following:

- Hydrological drought: concerns the effects of dry periods on surface and subsurface flows and stocks and is therefore related to blue water. Examples of associated indicators are surface water supply index (Shafer and Dezman, 1982), Palmer Hydrological Drought Index (Karl, 1986) and several indicators reviewed by Smakhtin (2001).

- Blue water scarcity: measures demand for blue water resources versus blue water availability and is thus purely related to blue water. Examples of associated indicators are the water crowding indicator (Falkenmark et al., 1989), the withdrawal-to-discharge ratio (Vörösmarty et al., 2000), water poverty index (Sullivan et al., 2003), water stress indicator (Smakhtin et al., 2004), water stress index (Pfister et al., 2009), dynamic water stress index (Wada et al., 2011) and blue water scarcity (Hoekstra et al., 2012). Note that some of these indicators also incorporate more than only physical elements of water scarcity (e.g. water poverty index).

The concepts related to broader forms of water scarcity than physical water scarcity that are outside the scope of this paper are the following:

- Socio-economic drought: concerns imbalances in supply and demand of economic goods due to the physical characteristics of drought (Wilhite and Glantz, 1985; American Meteorological Society, 2013) with effects on the economy and society. The American Meteorological Society (2013) mentions the following effects: loss of income from lower crop yields, reduced spending in rural communities, health issues and mass migration.

- Social resource scarcity: see Sect. 2.1.

Furthermore, the review and classification in this paper excludes indicators that measure drought by combining multiple drought indicators (classified individually) and sometimes other information such as land use maps. Examples of such indicators are the US Drought Monitor (Svoboda et al., 2002) and the Vegetation Drought Response Index (Brown et al., 2008).

\section{Green water availability and scarcity indicators}

We have identified around 80 indicators of green water availability and scarcity, which we classify into the following categories:

1. Green water availability indicators show whether green water availability is low or high and are insensitive to actual water demand. In other words, when the water demand increases, indicator values will not reflect this. Within this category we distinguish absolute and relative green water availability indicators:

(a) Absolute green water availability indicators measure actual conditions of green water availability (in an absolute sense).

(b) Relative green water availability indicators measure actual conditions of green water availability compared to conditions that are perceived as normal, which is often defined as the climate-average or median value of the variable of interest.

Note that this distinction between absolute and relative indicators is unrelated to and different from the concepts of relative and absolute scarcity earlier discussed in Sect. 2.2.

1. Green water scarcity indicators incorporate elements of both water availability and demand and therefore respond - in contrast to green water availability indicators - to changes in water demand as well. We distinguish three different options to measure green water scarcity conceptually (explanation in Sect. 3.2):

(a) green water crowding;

(b) green water requirements for self-sufficiency versus green water availability;

(c) actual green water consumption versus green water availability.

The usage of terms like water availability and water demand can be confusing because in different contexts they have different meanings. The term green water availability is basically used in two different ways. When we speak of green water availability indicators (Sect. 3.1), we refer to indicators that measure the availability of green water in one way or another, without considering availability in relation to an actual demand for green water. This is in contrast with green water scarcity indicators that always compare demand to availability. In the case of green water scarcity indicators, the term green water availability specifically refers to the part of the green water flow available for biomass production for human purposes (Sect. 3.2). Also the term demand occurs in two different contexts. When we speak of demand in the context of green water scarcity, we refer to the demand for green water, associated with the production of biomass for human purposes. In the discussion of agricultural drought indicators in Sect. 3.1, the term crop moisture/evaporation/water demand is used to refer to the water needs of the crop for non-water limited growth.

The indicator categories will be discussed in the following sections. Table 1 provides an overview of the categories and summarizes what they measure, which human factors directly influence them and what they are used for. Furthermore, the conceptual diagram in Fig. 1 displays the indicator categories and the factors that influence them. 
Table 1. Overview of indicator categories.

\begin{tabular}{lll}
\hline $\begin{array}{l}\text { Indicator category (parent cat- } \\
\text { egory) }\end{array}$ & Measures & $\begin{array}{l}\text { Human factors of direct influ- } \\
\text { ence }\end{array}$ \\
\hline $\begin{array}{l}\text { Aridity (absolute green water } \\
\text { availability) }\end{array}$ & $\begin{array}{l}\text { Long-term annual climatic } \\
\text { balance between precipitation } \\
\text { and evaporation. }\end{array}$ \\
\hline $\begin{array}{l}\text { Agricultural drought (absolute } \\
\text { green water availability) }\end{array}$ & $\begin{array}{l}\text { Actual soil moisture availabil- } \\
\text { ity versus crop water demand } \\
\text { for non-water limited growth. }\end{array}$ & $\begin{array}{l}\text { Soil management affecting } \\
\text { infiltration and groundwater } \\
\text { rechangement. (percolation); crop } \\
\text { management. }\end{array}$
\end{tabular}

Absolute soil moisture (absolute green water availability)
Actual soil moisture availability.
Soil management affecting infiltration and groundwater recharge (percolation).

Purposes

Classification of climates; characterization of (semi)-arid zones.

Assessing the extent to which crop growth is adversely affected by limiting soil moisture conditions; linking drought conditions to yield losses.

Monitoring spatial and temporal variation in soil moisture availability; analysing the correlation between soil moisture availability and crop evaporation and yields; warning for onset of agricultural drought.

Agricultural suitability under rain-fed conditions (absolute green water availability)
Land suitability for rain-fed crop production based on climate-average temperature and precipitation conditions, crop and soil characteristics and terrain slope.
Meteorological drought (relative green water availability)
Whether there is relatively little precipitation or whether the normal balance between precipitation and potential evaporation is distorted.
Level of agricultural inputs and management.
Agro-ecological zoning; determining a location's potential for rain-fed agriculture (yield gap analysis).

\section{$-$}

Drought monitoring as a basis for early warning systems and decision-support tools; assessing drought severity based on intensity, duration and spatial extent; comparison of historic drought events.

Assessment of drought impact on vegetation; early drought detection; studying the correlation between vegetation health and soil moisture availability, thermal conditions and crop yields.

Monitoring spatial and temporal variation in relative soil moisture availability; analysing the correlation between soil moisture availability and crop yields. recharge (percolation).
Pruning or clearing; prevention of plant disease. $\begin{array}{ll}\text { Relative soil moisture (relative } & \text { Whether the soil is } \\ \text { green water availability) } & \text { wetter than normal. }\end{array}$
Greenness of vegetation relaof greenness
Studying green water availability in relation to hypothetical green water requirements for self-sufficiency; identifying geographic areas that have too limited green water availability for self-sufficiency and are dependent on blue water resources and virtual water import (assessing food security). 
Table 1. Continued.

\begin{tabular}{|c|c|c|c|}
\hline $\begin{array}{l}\text { Green water requirements for } \\
\text { self-sufficiency versus green } \\
\text { water availability (green water } \\
\text { scarcity) }\end{array}$ & $\begin{array}{l}\text { Idem to green water crowding } \\
\text { indicators. }\end{array}$ & $\begin{array}{l}\text { Consumption pattern (diet } \\
\text { composition); population } \\
\text { growth; crop and soil man- } \\
\text { agement affecting water } \\
\text { productivities; land use } \\
\text { changes. }\end{array}$ & $\begin{array}{l}\text { Idem to green water crowding } \\
\text { indicators. }\end{array}$ \\
\hline $\begin{array}{l}\text { Actual green water consump- } \\
\text { tion versus green water avail- } \\
\text { ability (green water scarcity) }\end{array}$ & $\begin{array}{l}\text { The degree to which the avail- } \\
\text { able green water resources in } \\
\text { a geographic area have been } \\
\text { appropriated, i.e. the extent to } \\
\text { which the green water foot- } \\
\text { print has reached its maximum } \\
\text { sustainable level. }\end{array}$ & $\begin{array}{l}\text { Consumption pattern (diet } \\
\text { composition); population } \\
\text { growth; production pattern; } \\
\text { crop and soil management } \\
\text { affecting water productivities; } \\
\text { land use changes. }\end{array}$ & $\begin{array}{l}\text { Studying the competition over } \\
\text { limited green water resources } \\
\text { and allocation over competing } \\
\text { demands. }\end{array}$ \\
\hline
\end{tabular}

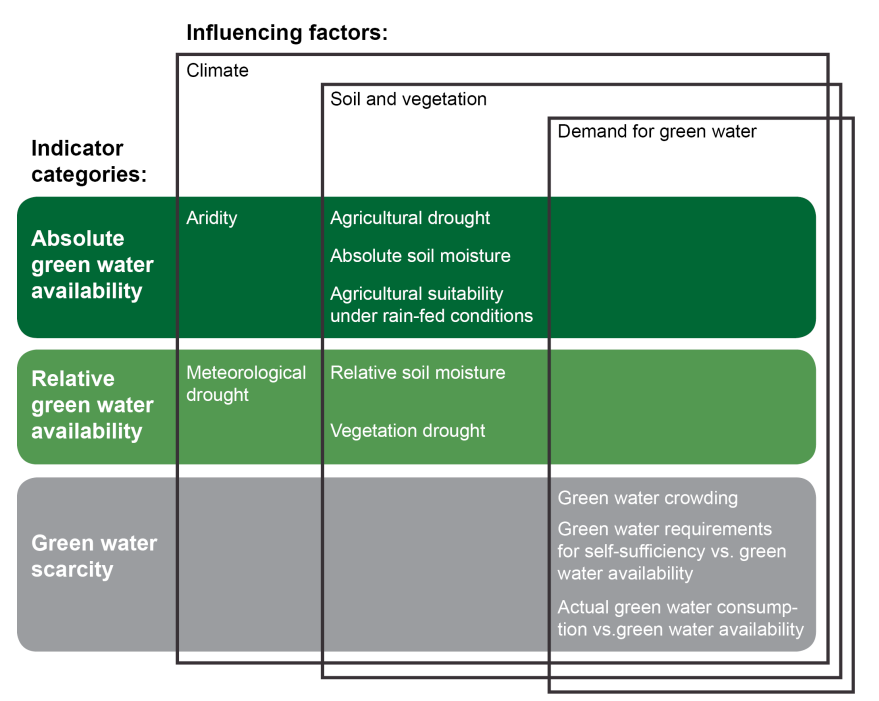

Figure 1. Conceptual diagram of indicator categories and the factors that influence them.

\subsection{Green water availability indicators}

Indicators of green water availability fall apart in indicators that measure availability in an absolute sense or in terms of relative to normal conditions. These two categories are treated in the next two subsections. Descriptions of various specific green water availability indicators that fall in the two categories are included in Appendices A and B. The indicator abbreviations used in this section are defined in these appendices.

\subsubsection{Absolute green water availability indicators}

Indicators in this category measure green water availability in a certain area (or location) and period (or moment) in an absolute sense. We find here indicators of aridity, agricultural drought, soil moisture and agricultural suitability, which are subsequently discussed in the following. Aridity indicators are purely climatic, while the others are also influenced by the characteristics and management of the soil and vegetation.

\section{Aridity indicators}

Aridity is seen as a permanent feature of a climate, consisting of low average annual precipitation and/or high evaporation rates, often resulting in low soil moisture availability (Pereira et al., 2002; Heim, 2002; Kallis, 2008). As such, one can say that an aridity map shows the preconditions for vegetation (Falkenmark and Rockström, 2004). Aridity indicators are usually based on long-term average annual comparisons of precipitation versus potential evaporation, temperature or atmospheric saturation deficit, whereby the latter two were often used in the twentieth century as proxies for potential evaporation due to lack of data. They have been used for the classification of climates, specifically the characterization of (semi-)arid zones. Some more recently developed aridity indicators compare the actual rather than potential evaporation rate with precipitation (ER, HU-ER). These indicators reflect the actual availability of water at a given location (also from lateral fluxes) for meeting the evaporative demand of the atmosphere.

The SCMD by Wilhelmi et al. (2002) is somewhat different than the classical aridity indicators. It shows the probability of seasonal crop moisture deficiency based on a combination of long-term precipitation records and area-weighted evaporation of the mixture of crops grown in the study area. Wilhelmi and Wilhite (2002) apply the SCMD to assess agricultural drought vulnerability in Nebraska. We classify the SCMD here under the aridity indicators, because like most aridity indicators, it measures precipitation versus evaporation and is calculated for a historical time period, thus representing a long-term average. 


\section{Agricultural drought indicators}

According to the World Meteorological Organization (1975), agricultural drought indicators "indirectly express the degree to which growing plants have been adversely affected by an abnormal moisture deficiency", which may be the result of an unusually small moisture supply or an unusually large moisture demand (World Meteorological Organization, 1975). Formulated differently by Sivakumar (2011): "Agricultural drought depends on the crop evapotranspiration demand and the soil moisture availability to meet this demand."

Therefore, the bulk of agricultural drought indicators measures crop-available water compared to crop water needs for non-water limited growth (i.e. potential evaporation) and are usually applied on a daily, weekly, monthly or seasonal basis (Woli et al., 2012). Some indicators measure the plant water deficit more specifically by looking at the difference between actual and potential transpiration (e.g. DTx and WDI). Agricultural drought indicators can be influenced by soil management that affects the rates of infiltration and percolation and thus the water available to the crop.

Drought is typically a relative-to-normal phenomenon as will be discussed in Sect. 3.1.2. Agricultural drought indicators, which measure actual relative to potential evaporation, are relative indicators in another way, though. They do not compare actual with normal conditions. Instead, they compare moisture supply with a crop water demand in the ideal case of non-water limited growth. Therefore these indicators actually measure absolute green water availability (actual evaporation), set against this crop water demand. In fact, these indicators say more about the demand for blue water (irrigation) to ensure non-water limited crop growth than they do about green water availability. Some indicators do somehow compare the actual to potential evaporation ratio with a multi-year average (or median) of this ratio and are thus in essence relative indicators according to our classification. Examples are the CMI, DSI and GrWSI and anomalies of the ESI and WS. Nevertheless, they are classified as agricultural drought indicators because they, like most of the others, measure actual to potential evaporation.

A note is required on the GWSI by Nunez et al. (2013) of which the name suggests that it is a green water scarcity indicator. Nevertheless, we classify it as an agricultural drought indicator, because it measures actual moisture supply versus crop-specific reference evaporation, albeit on a larger timescale (3-year crop rotation) than most other agricultural drought indicators.

\section{Absolute soil moisture indicators}

Multiple indicators provide a measure of the absolute amount of soil moisture available at a given location and moment (or summed over a period), be it on the basis of field measurements (e.g. SMIX, SMI) and/or modelling of the soil water balance (e.g. Avg-GWS and SD-GWS) or remote sens- ing data (e.g. TVDI, MPDI). They can be used for monitoring spatial and/or temporal variations in soil moisture availability. Temporal analysis of soil moisture availability can warn for the onset of agricultural drought, or in contrast, the proneness to flash floods (Hunt et al., 2009). Several of these indicators have been introduced and applied as indicators of agricultural drought (e.g. ADD, SMDI, SMIX, SMI), analysing the correlation between soil moisture availability and crop yields. Therefore, they are typically calculated on intra-annual timescales.

It should be noted that the soil moisture can partially be blue - also under rain-fed conditions - due to capillary rise or natural flooding (Sect. 2.3). This note also applies to the other indicators that are not purely based on climatic factors (Fig. 1).

\section{Agricultural suitability under rain-fed conditions}

Maps that classify land according to agricultural suitability under rain-fed conditions (green water only) are indirect measures of green water availability in the absolute sense. Up to date, two global studies have made such land suitability classifications for rain-fed crop production for climateaverage temperature and precipitation conditions and taking into account crop characteristics, various soil parameters and terrain slope: GAEZ (IIASA/FAO, 2012) and GLUES (Zabel et al., 2014). The GAEZ study additionally considers various levels of agricultural input/management. Both studies classify lands as not suitable, marginally suitable, moderately suitable or highly suitable. This classification shows where the climate, soil and topographic conditions are more or less suitable for agricultural production with green water only. In other words, where aridity maps show the preconditions for vegetation in general (Falkenmark and Rockström, 2004), these maps show the preconditions for rain-fed crop production, therein considering crop, soil and terrain parameters in addition to climate.

\section{.2 Relative green water availability indicators}

Indicators in this category measure green water availability relative to a normal condition and are usually calculated on intra-annual scales. As opposed to aridity, drought is often defined as a condition relative to what is perceived as a normal amount of precipitation or balance between precipitation and evaporation (World Meteorological Organization, 1975; Wilhite and Glantz, 1985). Droughts are often termed temporary, uncertain and difficult to predict features characterized by lower-than-average precipitation (Pereira et al., 2002; Heim, 2002; Kallis, 2008; Mishra and Singh, 2010; FAO, 2015). Therefore, indicators of meteorological drought and vegetation drought are classified into the category of relative green water availability indicators. Indicators that measure soil moisture in a relative sense are included in this category as well. Just like aridity indicators, meteorological drought 
indicators are solely based on climatic variables. The other two subcategories are also affected by the soil and vegetation and how they are managed. The three subcategories are sequentially discussed in the following.

\section{Meteorological drought indicators}

Meteorological drought indicators fall apart in indicators that are solely based on precipitation (e.g. SPI) and those that consider both precipitation and potential evaporation (e.g. PDSI, RDI, SPEI). These indicators show whether there is relatively little precipitation or whether the normal balance between precipitation and evaporation is distorted. Unlike aridity indicators, which are generally based on long-term annual averages reflecting climate, these indicators capture variations in the weather. They are applied for monitoring the intensity, duration and spatial extent of droughts and determining drought severity based on these characteristics. This is useful for recognizing droughts and comparing them with past drought, which serves as a basis for early warning systems and decision-support tools.

\section{Vegetation drought indicators}

Vegetation drought indicators show the drought impact on vegetation by measuring the weather-related variations in greenness of vegetation. They reflect whether vegetation greenness is deviating from regular conditions. They can be used for studying the correlation between vegetation health and soil moisture availability, thermal conditions and crop yields (Kogan, 2001). Since the vegetation drought indicators we have identified are all based on remote sensing observations, the indicators do not directly show whether deviations are caused by relatively dry weather (i.e. meteorological drought) or by other factors influencing vegetation growth (e.g. plant diseases or human interference such as pruning and clearing). Satellite-based vegetation drought indicators respond to subtle changes in vegetation canopy, which makes them suitable for early drought detection (Kogan, 2001).

\section{Relative soil moisture indicators}

In contrast to the absolute soil moisture indicators discussed in Sect. 3.1.1, these indicators measure the moisture conditions at a given location relative to a normal condition. Identified examples are the PZI, SMAI and SD. These indicators have similar uses as absolute soil moisture indicators. They are also used to correlate soil moisture conditions to crop yields and are considered suitable for measuring agricultural droughts (Keyantash and Dracup, 2002; Narasimhan and Srinivasan, 2005).

\subsection{Green water scarcity indicators}

As put forward in Sect. 2, water scarcity pertains to a situation with a high water demand compared to water availabil- ity, which is experienced by a community (numerous people) within a certain geographic area (e.g. catchment or country) over a significant period of time (months or years). We can then define green water scarcity as the degree of competition over limited green water resources, whereby the demand for green water resources to sustain the production of a desirable level of biomass-based products within a certain geographic area is somehow compared to the available green water resources in space and time.

Since production of biomass-based products (food, fibres, biofuels, timber) generally takes place in cycles of 1 year (or more in case of perennials and forestry), this definition of green water scarcity incorporates the significant-period-oftime element in the imbalance between green water demand and availability. Furthermore, limited production of biomassbased products affects numerous people, both producers and consumers.

As opposed to the indicators discussed in Sect. 3.1, indicators of green water scarcity thus need to include a measure of green water demand, associated with the production of biomass for human purposes, compared to green water availability. In other words, they should measure the green water demand related to crop production, grazing lands and forestry in relation to green water availability. Note that the term green water availability here refers to the part of the green water flow available for biomass production for human purposes (in space and time); it thus excludes green water flows that are effectively unavailable, for instance green water flows in unsuitable areas (e.g. because of steep slopes) or green water flows in cold parts of the year unsuitable for growth.

We distinguish three different options to measure green water scarcity conceptually:

1. green water crowding: per capita available green water resources in an area compared to a global average threshold representing the amount of green water required to sustain a person's standard consumption pattern of biomass-based products;

2. green water requirements for self-sufficiency versus green water availability: green water requirements for producing the consumed biomass-based products within a certain geographic area, assuming self-sufficiency within the geographic area, compared to the green water resources in the geographic area;

3. actual green water consumption versus green water availability: actual green water consumption in a certain geographic area (associated with the actual production of biomass for human purposes) compared to green water availability in the area. This type of indicator thus acknowledges the possibility of virtual water trade as opposed to assuming self-sufficiency as in the previous two types of indicators. 
In Sect. 3.2.1 and 3.2.2, we discuss existing indicators that measure overall green-blue water scarcity and reflect on how these indicators could be adapted to measure green water scarcity specifically, according to above-mentioned options (1) and (2). In Sect. 3.2.3, we elaborate upon a third way of measuring green water scarcity that has yet to be brought into practice. The challenges for operationalization of these green water scarcity indicators are discussed in Sect. 3.2.4. Finally, in Sect. 3.2.5 we reflect on green water scarcity indicators versus indicators that measure overall green-blue water scarcity.

\subsubsection{Green water crowding}

Rockström et al. (2009) introduced a combined green-blue water shortage index, which compares the sum of green and blue water availability with a global average threshold of $1300 \mathrm{~m}^{3} \mathrm{cap}^{-1} \mathrm{yr}^{-1}$. This threshold represents the green and blue water requirements for sustaining a global average standard diet. When green-blue water availability drops below the threshold, this indicates a shortage of green-blue water resources in the study area and reflects the area's dependency on external water resources. The green-blue water shortage index is an indicator of water crowding, similar to Falkenmark's blue-water-focussed water crowding indicator (Falkenmark et al., 1989).

Similar to the indicator by Rockström et al. (2009), an indicator of green water crowding could be defined as the per capita available green water resources in an area compared to a global average threshold representing the amount of green water required to sustain a person's standard consumption pattern. We intentionally speak here of a consumption pattern, because green water is required not only to produce food, but also to produce other biomass-based products humans consume, such as fibres, biofuels and forestry products. As such, the measure of green water requirements we propose here is broader than the definition of a standard diet according to Rockström et al. (2009) (and Gerten et al., 2011; Kummu et al. 2014), which only pertains to water requirements for food production.

Rockström et al. (2009) define green water availability as "the soil moisture available for productive vapour flows from agricultural land". Technically, they calculate green water availability as actual evaporation from existing cropland and permanent pasture, reduced by a factor 0.85 that accounts for minimum evaporation losses that are unavoidable in agricultural systems (Rockström et al., 2009). This definition is dependent on the extent of agricultural land and excludes available green water on lands that are currently uncultivated, but have potential to be used productively in a sustainable manner.

\subsubsection{Green water requirements for self-sufficiency versus green water availability}

Gerten et al. (2011) and Kummu et al. (2014) elaborated on the work by Rockström et al. (2009) by further developing and applying the overall green-blue water scarcity indicator. Instead of using a global average, Gerten et al. (2011) calculate the green-blue water requirements for sustaining a standard diet on the national level based on local crop water productivities and compare this with the sum of green and blue availability in each country of the world. The resulting green-blue water scarcity indicator, computed for each country, is defined as the ratio between green-blue water availability and green-blue water requirements for producing the standard diet. They define green water availability similar to Rockström et al. (2009), but a bit more conservative: they do not assume year-round evaporation from areas covered with their category of other crops that they parameterized as perennial grass, since this category includes non-food crops and crops that grow only during a part of the year (Gerten et al., 2011).

Whereas the studies by Rockström et al. (2009) and Gerten et al. (2011) are based on climate-averages, Kummu et al. (2014) apply the green-blue water scarcity indicator by Gerten et al. (2011) on a year-by-year basis to account for inter-annual climate variability on the scale of food producing units, the scale at which demand for water and food is assumed to be managed according to the authors. Kummu et al. (2014) measure the frequency of years in which greenblue water availability falls short of green-blue water requirements, on which they base their classification of greenblue scarcity: no scarcity, occasional scarcity (subdivided in four levels) or chronic scarcity.

The green-blue water scarcity indicator shows the potential of a geographic area (e.g. country or food producing unit) to reach food self-sufficiency and reflects its dependency on trade in agricultural commodities and associated virtual water (Kummu et al., 2014). A similar indicator for green water could show an area's green water demand (for self-sufficiency in biomass-based products, for sustaining the standard consumption pattern) compared to green water availability in the area. It would also reflect an area's dependency on internal blue water resources and virtual water trade.

For the potential green water scarcity indicators discussed in Sect. 3.2.1 and 3.2.2, a more comprehensive definition of green water availability is advised than the one applied by Rockström et al. (2009), Gerten et al. (2011) and Kummu et al. (2014). An example of a more comprehensive definition is discussed in the following section. 


\subsubsection{Actual green water consumption versus green water availability}

The green water scarcity indicator by Hoekstra et al. (2011) compares the actual green water consumption in an area associated with the actual biomass production pattern (hence considering virtual water trade as opposed to assuming selfsufficiency) with green water availability in the area. Green water scarcity is defined as the ratio of the total green water footprint in a catchment in a period (e.g. a year) over green water availability.

The sum of green water footprints equals all actual evaporation $\left(E_{\text {act }}\right)$ related to biomass production for human purposes (i.e. agriculture and forestry) excluding the part of the vapour flow that originates from blue water resources (irrigation). Note that for cases where land use is partly natural and partly for human production (e.g. a semi-natural production forest), the green water demand related to human production would need to be expressed as a fraction of the total green water flow. Methods to do so for a production forest are discussed by van Oel and Hoekstra (2012). Green water availability is defined as total $E_{\text {act }}$ over the catchment minus $E_{\text {act }}$ from land reserved for natural vegetation (so-called environmental green water requirement) and minus $E_{\text {act }}$ from land that cannot be made productive, e.g. in areas or periods of the year that are unsuitable for crop growth (Hoekstra et al., 2011). In fact, green water availability defined like this, represents the maximum sustainable green water footprint in the catchment and period under consideration. Hence, the green water scarcity ratio shows the extent to which the green water footprint has reached its maximum sustainable level. Of course, this definition can also be applied to other geographical units than a catchment.

The definition of green water availability by Hoekstra et al. (2011) is more comprehensive than the one used by Rockström et al. (2009), Gerten et al. (2011) and Kummu et al. (2014). However, this is also the reason why the indicator has not been made operational yet. Difficulties remain in estimating the amount of land that needs to be reserved for nature and when and where the green water flow cannot be made productive (Hoekstra et al., 2011). These challenges are discussed in the following section.

Furthermore, the indicator does not deal with green water scarcity at a particular site as looked upon by Falkenmark et al. (2007) and Falkenmark (2013a). They describe green water scarcity as an issue of lower-than-potential plantaccessible water in the root zone and the occurrence of unproductive evaporation losses from the field, which results in lower yields than potentially achievable. First, blue water losses in the form of surface run-off and percolation decrease the plant-accessible water in the root zone (smaller green water flow) (Rockström and Falkenmark, 2000). Such losses are the result of a soil's low infiltration capacity (e.g. soil crusting) and poor soil water holding capacity, but can be caused or aggravated by human action through soil mismanagement
(Falkenmark, 2013a). Second, low root/crop water uptake capacity leads to unproductive evaporation losses (green water flow not entirely productive) (Rockström and Falkenmark, 2000). Transpiration is a productive form of green water use, contributing to biomass production, while other components of the evaporative flow are regarded as unproductive (Rockström and Falkenmark, 2000; Rockström, 2001; Rockstrom et al., 2007; Savenije, 2004). Rockstrom et al. (2007) express the productivity of green water use as the ratio of transpiration to evaporation. Rockström et al. (2009) call this the transpiration efficiency. This transpiration efficiency is complementary to the green water scarcity indicator by Hoekstra et al. (2011). A green water scarcity assessment based on both will give insight into the severity of green water scarcity: areas that are considered highly green-water scarce, but have a low transpiration efficiency, may have options to improve the latter and thereby yields, which may lower the green water scarcity.

\subsubsection{Challenges for operationalization of green water scarcity indicators}

Operationalization of green water scarcity indicators faces three major challenges, particularly regarding the quantification of green water availability.

First, the determination of which areas and periods of the year the green water flow can be used productively is not straightforward. Absolute green water availability indicators, in particular land classifications of agricultural suitability, can provide insight in the availability of green water in the spatial dimension. Relative green water availability indicators can enrich the picture by showing which areas are prone to large inter- and intra-annual variations in green water availability, making these areas less suitable for (certain types of) biomass production. To estimate which part of the green water flow can be used productively in time, advanced crop growth models (like APSIM, McCown et al., 1995 and Holzworth et al., 2014; AquaCrop, Steduto et al., 2009; CropSyst, Stöckle et al., 2003; EPIC, Jones et al., 1991 or SWAP/WOFOST, van Dam et al., 2008) can be used to simulate water-limited yields and actual evaporation for various cropping periods and different types of soil, crop and agricultural water management (e.g. adding blue water in the form of deficit irrigation during a dry spell, might make it possible for the crop to survive and use the green water flow later in the year productively).

Second, estimating green water consumption of forestry is difficult, because it entails separation of production forest evaporation into green and blue parts. This is problematic, because trees generally root so deep that, by means of capillary rise, they directly take up water from groundwater (blue) in addition to the soil moisture (green) (Hoekstra, 2013).

Third, research is required to determine the environmental green water requirements, i.e. the green water flow that should be preserved for nature, similar to the environmen- 
tal flow requirements for blue water. Key here is the identification of areas that need to be reserved for nature and biodiversity conservation. It is known that the current network of protected areas is insufficient to conserve biodiversity (Rodrigues et al., 2004a, b; Venter et al., 2014; Butchart et al., 2015) and that attention should be paid to conservation of biodiversity in production landscapes that are shared with humans (Baudron and Giller, 2014). The 11th Aichi Biodiversity Target is to expand the protected area network, which currently has a terrestrial coverage of about $14.6 \%$ (Butchart et al., 2015), to at least 17\% terrestrial coverage by 2020 (Convention on Biological Diversity, 2010). However, to properly assess the limitations to green water availability, spatially explicit information on the additional areas to be preserved is required. The best-available data regarding this are recently published work by Montesino Pouzols et al. (2014). These authors have mapped global and national priority areas for expansion of the protected area network on 0.2 degree spatial resolution and assessed associated conservation gains (Montesino Pouzols et al., 2014; Brooks, 2014).

\subsubsection{Measuring green water scarcity versus overall green-blue water scarcity}

In Sect. 3.2.1 and 3.2.2, we mentioned a few indicators that measure overall green-blue water scarcity (Rockström et al., 2009; Gerten et al., 2011; Kummu et al., 2014). Whereas useful for getting an overall picture of water scarcity, a disadvantage of these indicators is that a high degree of green water scarcity can be masked by a low degree of blue water scarcity and vice versa. Imagine for example a river basin where nearly all land is in use and natural forest is under pressure by conversion to cropland (high degree of green water scarcity), while there is enough blue water available to irrigate croplands if necessary (low degree of blue water scarcity). Measuring increasing green water scarcity could be relevant, for instance, for the Amazon basin in South America, where increasingly natural forest and associated green water flows are turned into use and competition is essentially about land and associated green water resources, while blue water resources are abundant and blue water scarcity is low. Therefore, for studying green water scarcity, an indicator specifically comparing green water demand and green water availability can be more appropriate.

\section{Conclusions and future research}

In this paper we have reviewed and classified around 80 indicators of green water availability and scarcity. This list of indicators is extensive, but not exhaustive. Nevertheless, we are confident to have identified the most widely used and cited indicators.

The number of green water availability indicators by far outnumbers the existing green water scarcity indicators. This reflects that the concept of green water scarcity is still largely unexplored. Indicators of overall green-blue water crowding and scarcity have been developed by Rockström et al. (2009), Gerten et al. (2011) and Kummu et al. (2014). These have potential to be tailored to measure green water crowding and green water requirements for self-sufficiency versus green water availability. The green water scarcity indicator by Hoekstra et al. (2011) measures actual green water consumption versus green water availability, but has not yet been operationalized due to several challenges discussed in Sect. 3.2.4. The biggest challenge is to determine which part of the green water flow can be made productive in space and time. Application of both absolute and relative green water availability indicators will provide insight into where the green water flow can be made productive for human purposes. Simulations with crop growth models for different management strategies can be used to assess during which parts of the year the green water flow can be made productive.

Future research should be aimed at overcoming these challenges to make the green water scarcity indicators discussed in this paper operational. We also encourage the development of additional definitions of green water scarcity indicators to the ones discussed here. The conceptual definition of green water scarcity we introduced in Sect. 3.2 can be a starting point for this.

Despite scientific obstacles on the way, it is time that the scope of water scarcity assessments is broadened to include green water. We hope that this paper is a stepping stone towards this goal by bringing structure in the large pool of green water availability indicators and discussing the way forward to develop operational green water scarcity indicators. Practitioners and scholars might also find the classification of indicators provided in this paper insightful and helpful for choosing the indicator that suits their purpose. 
Appendix A: Absolute green water availability indicators

Absolute green water availability indicators are included in Tables A1 to A4. The following are some often used symbols in this appendix: $E_{\text {act }}$ is actual evaporation, $E_{\text {pot }}$ potential evaporation, $E_{\text {pot,c }}$ crop-specific potential evaporation, $E_{\text {pot,ref potential evaporation of FAO reference crop, } P \text { pre- }}$ cipitation, $S$ soil moisture, $T$ air temperature, $\operatorname{Tr}_{\text {act }}$ actual transpiration and $\operatorname{Tr}_{\text {pot }}$ potential transpiration. 
Table A1. Aridity indicators.

\begin{tabular}{|c|c|c|c|}
\hline Name & Abbreviation & Formula/description & Reference \\
\hline Rainfall-evaporation ratio & RER & $\frac{P}{E_{\mathrm{ow}}}$ is open-water evaporation. & Transeau (1905) \\
\hline Rain factor & $\mathrm{RF}$ & $\frac{P}{T}$ & Lang (1920) \\
\hline Koloskov index & $\mathrm{KI}$ & $\sum_{\text {Sum over vegetative period }}^{P T}$ & $\begin{array}{l}\text { Koloskov (1925) as cited } \\
\text { by World Meteorological } \\
\text { Organization (1975) }\end{array}$ \\
\hline de Martonne's aridity index & dM-AI & $\frac{P}{T+10}$ & $\begin{array}{l}\text { de Martonne (1926) as } \\
\text { cited by Thornthwaite } \\
\text { (1931), Budyko (1958) } \\
\text { and de Martonne (1942) }\end{array}$ \\
\hline $\begin{array}{l}\text { Precipitation-saturation } \\
\text { deficit ratio }\end{array}$ & PDR & $\begin{array}{l}\frac{P}{D} \\
D \text { is mean annual atmospheric saturation deficit. }\end{array}$ & $\begin{array}{l}\text { Meyer (1926) as cited by } \\
\text { Thornthwaite (1931) and } \\
\text { Budyko (1958) }\end{array}$ \\
\hline Reichel's aridity index & R-AI & $\begin{array}{l}\frac{N \times P}{T+10} \\
N \text { is number of rainy days. }\end{array}$ & $\begin{array}{l}\text { Reichel (1928) as cited } \\
\text { by Perez-Mendoza et } \\
\text { al. (2013) }\end{array}$ \\
\hline Marcovitch's index & MI & $0.5 L^{2} \times\left(\frac{100}{P}\right)^{2}$ & Marcovitch (1930) \\
\hline Shostakovich index & SI & $\begin{array}{l}L \text { is the total number of } 2 \text { or more consecutive days } \\
\text { above } 90^{\circ} \mathrm{F} \text { for the months of June, July, August and } \\
\text { September; Total } P \text { for those months. } \\
\frac{P}{T} \\
P \text { during vegetative period and mean } T \text { over this period. }\end{array}$ & $\begin{array}{l}\text { Shostakovich (1932) as } \\
\text { cited by Jenny (1994) }\end{array}$ \\
\hline Emberger's aridity index & E-AI & $\begin{array}{l}\frac{100 P}{(M+m)(M-m)} \\
M \text { is mean temperature of the warmest month and } \\
m=\text { mean temperature of the coldest month. }\end{array}$ & $\begin{array}{l}\text { Emberger (1932) as cited } \\
\text { by Wallén (1967) }\end{array}$ \\
\hline $\begin{array}{l}\text { Precipitation-effectiveness in- } \\
\text { dex }\end{array}$ & $\mathrm{PE}$ & $\sum_{n=1}^{12} 10 \frac{P_{n}}{E_{\mathrm{pot}_{n}}}$ & Thornthwaite (1931) \\
\hline Hydrothermal coefficient & $\mathrm{HC}$ & $\frac{P}{\left.\sum T\right|_{T>10^{\circ} \mathrm{C}}}$ & $\begin{array}{l}\text { Selianinov (1930, 1937) } \\
\text { as cited by Budyko } \\
\text { (1958) and World Mete- } \\
\text { orological Organization } \\
(1975)\end{array}$ \\
\hline Köppen classification & $\mathrm{KC}$ & $\begin{array}{l}\text { Threshold for classifying area as semi-arid: } \\
P=2(T+14) \text { (summer rainfall) } \\
P=2 T \text { (winter rainfall) } \\
\text { Threshold for classifying area as arid: } \\
P=T+14 \text { (summer rainfall) } \\
P=T \text { (winter rainfall) } \\
P \text { is annual precipitation amount in } \mathrm{cm} \mathrm{yr}^{-1} \\
T \text { is mean annual temperature in }{ }^{\circ} \mathrm{C}\end{array}$ & Köppen (1931) \\
\hline Aridity coefficient & $\mathrm{AC}$ & $\begin{array}{l}f_{\text {lat }} \times\left(T_{\max }-T_{\min }\right) \times\left(\frac{P_{\max }-P_{\min }}{P_{\mathrm{avg}}}\right) \\
f_{\text {lat }} \text { is latitude factor, } T_{\max } \text { temperature of the long-term } \\
\text { mean warmest month, } T_{\min } \text { temperature of the long- } \\
\text { term mean coldest month, } P_{\max } \text { largest annual precip- } \\
\text { itation amount on record, } P_{\min } \text { smallest annual precip- } \\
\text { itation amount on record and } P_{\text {avg }} \text { average annual pre- } \\
\text { cipitation amount on record. }\end{array}$ & Gorczynski (1940) \\
\hline $\begin{array}{l}\text { Modified de Martonne aridity } \\
\text { index }\end{array}$ & MdM-AI & $\begin{array}{l}\frac{1}{2}\left(\frac{P}{T+10}+\frac{12 P_{\mathrm{d}}}{T_{\mathrm{d}}+10}\right) \\
P_{\mathrm{d}} \text { is precipitation in the driest month and } T_{\mathrm{d}} \text { tempera- } \\
\text { ture in the driest month. }\end{array}$ & de Martonne (1942) \\
\hline
\end{tabular}


Table A1. Continued.

\begin{tabular}{|c|c|c|c|}
\hline Name & Abbreviation & Formula/description & Reference \\
\hline Popov's aridity index & P-AI & $\begin{array}{l}\frac{P_{\text {eff }}}{2.4\left(t-t^{\prime}\right) r} \\
P_{\text {eff is annual amount of precipitation available to }} \\
\text { plants; } r=\text { factor depending on day length and } t-t^{\prime} \text { an- } \\
\text { nual mean wet bulb depression in }{ }^{\circ} \mathrm{C} \text {. }\end{array}$ & $\begin{array}{l}\text { Popov (1948) as cited } \\
\text { by World Meteorological } \\
\text { Organization (1975) }\end{array}$ \\
\hline $\begin{array}{l}\text { Moisture index, aridity index, } \\
\text { humidity index }\end{array}$ & $\mathrm{I}_{\mathrm{m}} ; \mathrm{I}_{\mathrm{a}} ; \mathrm{I}_{\mathrm{h}}$ & $\begin{array}{l}I_{\mathrm{a}}=\frac{100 d}{E_{\mathrm{pot}}} \\
I_{\mathrm{h}}=\frac{100 s}{E_{\mathrm{pot}}} \\
I_{\mathrm{m}}=I_{\mathrm{h}}-0.6 I_{\mathrm{a}} \\
\text { where } d \text { is a water deficiency when } P<E_{\mathrm{pot}} \text { and } s \text { is a } \\
\text { water surplus when } P>E_{\mathrm{pot}} \\
I_{\mathrm{m}} \text { is an overall measure of the moisture conditions of a } \\
\text { region, giving more weight to } I_{\mathrm{h}} \text {, since } s \text { in one season } \\
\text { can partially compensate for } d \text { in another season. }\end{array}$ & Thornthwaite (1948) \\
\hline Capot-Rey's aridity index & CR-AI & $\begin{array}{l}\frac{1}{2}\left(\frac{100 P}{E_{\mathrm{pot}}}+\frac{12 P_{\mathrm{w}}}{E_{\mathrm{pot}, \mathrm{w}}}\right) \\
P_{\mathrm{W}} \text { is precipitation of the wettest month of the year (in } \\
\left.\mathrm{cm} \text { month }{ }^{-1}\right) \text { and } E_{\mathrm{pot}, \mathrm{w} \text { potential evaporation of the }} \\
\left.\text { wettest month of the year (in cm month }{ }^{-1}\right) .\end{array}$ & Capot-Rey (1951) \\
\hline Radiational index of dryness & RID & $\begin{array}{l}\frac{R}{L \times P} \\
R \text { is mean annual net radiation and } L \text { latent heat of va- } \\
\text { porization of water }\end{array}$ & Budyko (1958) \\
\hline Gaussen classification & GC & $P \leq 2 T$ & UNESCO (1963) \\
\hline Sly's climatic moisture index & SCMI & $\begin{array}{l}\frac{P}{P+S+I} \\
I \text { is irrigation requirement for non-water limited } \\
\text { growth, } \\
P \text { and } I \text { during growing season and } S \text { at start of grow- } \\
\text { ing season. The index is made purely climatic by fixed } \\
\text { assumptions on the non-climatic factors. }\end{array}$ & Sly (1970) \\
\hline Moisture availability index & MAI-H & $\begin{array}{l}\frac{P_{\mathrm{dep}}}{E_{\mathrm{pot}}} \\
P_{\mathrm{dep}} \text { is dependable precipitation, which is the precipita- } \\
\text { tion amount with a specified probability of occurrence. }\end{array}$ & Hargreaves (1972) \\
\hline Evaporation ratio & ER & $\frac{E_{\text {act }}}{P}$ & Peixoto and Oort (1992) \\
\hline UNEP's aridity index & AI & $\frac{P}{E_{\mathrm{pot}}}$ & $\begin{array}{l}\text { Middleton and Thomas } \\
(1992,1997)\end{array}$ \\
\hline $\begin{array}{l}\text { Seasonal crop moisture defi- } \\
\text { ciency }\end{array}$ & SCMD & $\begin{array}{l}\text { Probability of seasonal crop moisture deficiency based } \\
\text { on a combination of long-term precipitation records and } \\
\text { area-weighted } E_{\text {act }} \text { of the mixture of crops grown in the } \\
\text { study area. } \\
\text { Although most crops studied by Wilhelmi et al. (2002) } \\
\text { are considered well-watered ( } E_{\text {act }}=E_{\text {pot,c }} \text { ), for wheat } \\
\text { and grasses } E_{\text {act }} \text { is estimated as the } E_{\text {act }} \text { associated with } \\
\text { a certain threshold yield, representing so-called critical } \\
\text { crop water requirements (Wilhelmi et al., 2002). }\end{array}$ & $\begin{array}{l}\text { Wilhelmi et al. (2002); } \\
\text { Wilhelmi and Wilhite } \\
(2002)\end{array}$ \\
\hline Climatic moisture index & CliMI & $\begin{array}{l}\frac{P}{E_{\mathrm{pot}}}-1 \text { when } P<E_{\mathrm{pot}} \\
1-\frac{E_{\mathrm{pot}}}{P} \text { when } P \geq E_{\mathrm{pot}}\end{array}$ & Vörösmarty et al. (2005) \\
\hline $\begin{array}{l}\text { Hydrologic unit evaporation } \\
\text { ratio }\end{array}$ & HU-ER & $\begin{array}{l}\frac{E_{\text {act }}}{P} \\
\text { Theoretically equivalent to ER (above), but applied to } \\
\text { the level of a hydrologic unit. }\end{array}$ & Weiskel et al. (2014) \\
\hline Green-blue index & GBI & $\begin{array}{l}\text { Indicates whether vertical precipitation and evaporation } \\
\text { fluxes dominate in a hydrologic unit (compared to lat- } \\
\text { eral blue water flows) during a period of interest. Dis- } \\
\text { tinction between semi-arid and arid areas can be made } \\
\text { when combined with a precipitation map. }\end{array}$ & Weiskel et al. (2014) \\
\hline
\end{tabular}


Table A2. Agricultural drought indicators.

\begin{tabular}{|c|c|c|c|}
\hline Name & Abbreviation & Formula/description & Reference \\
\hline Bova's drought index & BDI & $\begin{array}{l}\frac{10(S+P)}{\sum T} \\
S \text { (in mm) of the top } 100 \mathrm{~cm} \text { of soil at the beginning of } \\
\text { the growing season, } P \text { during growing season and sum } \\
\text { of } T \text { from the first day } T \text { is above } 0^{\circ} \mathrm{C} \text {. }\end{array}$ & $\begin{array}{l}\text { Bova (1941) as cited } \\
\text { by World Meteorologi- } \\
\text { cal Organization (1975) }\end{array}$ \\
\hline Moisture adequacy index & MAI & $\frac{P+S}{E_{\mathrm{pot}}}$ & $\begin{array}{l}\text { McGuire and Palmer } \\
\text { (1957) }\end{array}$ \\
\hline Water requirement satisfaction index & WRSI & $\begin{array}{l}\frac{E_{\mathrm{act}}}{E_{\mathrm{pot}} \times K_{\mathrm{c}}} \\
K_{\mathrm{c}} \text { is crop coefficient that accounts for the difference } \\
\text { in evaporation between the considered crop and a refer- } \\
\text { ence grass surface. } \\
\text { WRSI is usually evaluated as sum over the growing sea- } \\
\text { son. }\end{array}$ & $\begin{array}{l}\text { FAO (1986); Verdin and } \\
\text { Klaver (2002) }\end{array}$ \\
\hline Crop water stress index & CWSI & $1-\frac{E_{\mathrm{act}}}{E_{\mathrm{pot}}}$ & $\begin{array}{l}\text { Jackson et al. (1981); } \\
\text { Moran et al. (1994) }\end{array}$ \\
\hline Evaporative stress index & ESI & Idem to CWSI. & $\begin{array}{l}\text { Anderson et al. (2007a, } \\
\text { b); Yao et al. (2010) }\end{array}$ \\
\hline Water stress ratio & WS & $\begin{array}{l}\frac{E_{\mathrm{pot}}-E_{\mathrm{act}}}{E_{\mathrm{pot}}} \\
\text { In fact, idem to CWSI }\end{array}$ & $\begin{array}{l}\text { Narasimhan and Srini- } \\
\text { vasan }(2005)\end{array}$ \\
\hline Crop moisture index & CMI & $\begin{array}{l}\text { Abnormal evaporation deficit, defined as the difference } \\
\text { between } E_{\text {act }} \text { and climatologically expected weekly } \\
\text { evaporation. Whereby the latter is the normal value ad- } \\
\text { justed up or down according to the departure of the } \\
\text { week's temperature from normal (Wilhite and Glantz, } \\
\text { 1985). }\end{array}$ & Palmer (1968) \\
\hline Stress day index & SDI & $\begin{array}{l}\text { Product of a stress day factor (SD) that measures the } \\
\text { degree and duration of plant water deficit and a crop } \\
\text { susceptibility factor (CS), which is specific for the crop } \\
\text { species and growth stage, indicating a crop's suscep- } \\
\text { tibility to water deficit. Various definitions of SD are } \\
\text { proposed based on } \mathrm{Tr}_{\text {act }} \text { and } \mathrm{Tr}_{\text {pot }} \text { and/or leaf and soil } \\
\text { water potential. }\end{array}$ & Hiler and Clark (1971) \\
\hline Crop-specific drought index & CSDI & $\begin{array}{l}\prod_{i=1}^{n}\left(\frac{\sum E_{\mathrm{act}}}{\sum E_{\mathrm{pot}, \mathrm{c}}}\right)_{i}^{\lambda_{i}} \\
\text { Index } i \text { depicts the crop growth stage. Exponent } \lambda_{i} \text { ex- } \\
\text { presses the relative sensitivity of the crop to moisture } \\
\text { stress during stage } i \text {. } \\
\text { Meyer et al. (1993) initially developed the CSDI for } \\
\text { corn. Later on, the index was also applied for soybean, } \\
\text { wheat and sorghum (Wu et al., 2004). }\end{array}$ & Meyer et al. (1993) \\
\hline Integrated transpiration deficit & DTx & $\begin{array}{l}\sum_{i=1}^{\chi}\left(\operatorname{Tr}_{\text {pot }}-\operatorname{Tr}_{\mathrm{act}}\right) \\
\text { Transpiration deficit that has been built up during a pe- } \\
\text { riod of } x \text { days before. }\end{array}$ & Marletto et al. (2005) \\
\hline Actual to potential canopy conductance & $L_{\mathrm{TA}}$ & $\begin{array}{l}\frac{g_{\text {act }}}{g_{\text {pot }}} \\
\text { Ratio of actual to potential canopy conductance. It de- } \\
\text { scribes the extent to which transpiration and photosyn- } \\
\text { thesis are co-limited by soil water deficits (Gerten et al., } \\
2007) \text {. }\end{array}$ & Gerten et al. (2005) \\
\hline
\end{tabular}


Table A2. Continued.

\begin{tabular}{|c|c|c|c|}
\hline Name & Abbreviation & Formula/description & Reference \\
\hline $\begin{array}{l}\text { Agricultural reference index for } \\
\text { drought }\end{array}$ & ARID & $1-\frac{\operatorname{Tr}_{\mathrm{act}}}{E_{\mathrm{pot}, \mathrm{ref}}}$ & Woli et al. (2012) \\
\hline $\begin{array}{l}\text { MODIS Global Terrestrial } \\
\text { Drought Severity Index }\end{array}$ & DSI & $\begin{array}{l}\text { Standardized sum of the standardized ratio of } E_{\text {act }} \text { to } \\
E_{\text {pot and the standardized normalized difference vege- }} \\
\text { tation index (NDVI). The latter only during the snow- } \\
\text { free growing season. }\end{array}$ & Mu et al. (2013) \\
\hline Green water scarcity index & GWSI & $\begin{array}{l}\frac{\min \left(P_{\mathrm{eff}}, E_{\mathrm{pt}, \mathrm{c}}\right)}{P_{\text {eff }}} \\
\text { Ratio of the green water consumption of a } 3 \text {-year } \\
\text { crop rotation (in } \mathrm{m}^{3} \mathrm{~m}^{-2} \text { rotation } \\
\text { fective precipitation during the same period ( } P_{\text {eff }} \text { in } \\
\mathrm{m}^{3} \mathrm{~m}^{2} \text { rotation } \\
\text { tion as a proxy for crop-available green water. Green } \\
\text { water consumption is defined as the minimum of } P_{\text {eff }} \\
\text { and } E_{\mathrm{pot}, \mathrm{c}} \text {. Therefore, the index is } 1 \text { if } P_{\text {eff }} \leq E_{\mathrm{pot}, \mathrm{c}} \\
\text { and ranges from } 0 \text { to } 1 \text { if } P_{\text {eff }}>E_{\mathrm{pot}, \mathrm{c}} \text { It measures to } \\
\text { which extent available green water during the } 3 \text {-year } \\
\text { period was sufficient to meet the evaporative demand } \\
\text { of the crop rotation during that period. }\end{array}$ & Nunez et al. (2013) \\
\hline Green water stress index & GrWSI & $\frac{E_{\mathrm{act}} / E_{\mathrm{pot}}}{E_{\mathrm{act}} / E_{\mathrm{pot}}}$ & Wada (2013) \\
\hline
\end{tabular}


Table A3. Absolute soil moisture indicators.

\begin{tabular}{|c|c|c|c|}
\hline Name & Abbreviation & Formula/description & Reference \\
\hline Antecedent precipitation index & API & $\begin{array}{l}k \times \mathrm{API}_{i-1}+P_{i} \\
\text { API on day } i \text { is calculated by multiplying API of the } \\
\text { previous day with a factor } k(\text { e.g. } 0.9) \text { and adding the } \\
P \text { during day } i . \text { By combining the amount and timing } \\
\text { of precipitation, the index is a proxy for available soil } \\
\text { moisture. }\end{array}$ & McQuigg (1954) \\
\hline Agricultural drought day & $\mathrm{ADD}$ & $\begin{array}{l}\sum_{i=1^{L}} \text { day } \mid \theta \leq \theta_{\mathrm{wp}} \\
L=\text { length of the period considered }\end{array}$ & Rickard (1960) \\
\hline Kulik's drought indicator & $\mathrm{KU}$ & $\begin{array}{l}\sum_{S} \mid \text { day }\left.\right|_{S<S_{\text {thres }}} \\
S \text { in tilled layer of soil (top } 20 \mathrm{~cm} \text { ). }\end{array}$ & $\begin{array}{l}\text { Kulik (1958) as cited } \\
\text { by World Meteorological } \\
\text { Organization (1975) }\end{array}$ \\
\hline
\end{tabular}

\begin{tabular}{|c|c|c|}
\hline Keetch-Byram drought index & KBDI & $\begin{array}{l}\text { The amount of net precipitation (precipitation minus } \\
\text { evaporation) that is required to fill up the soil moisture }\end{array}$ \\
\hline
\end{tabular}

Keetch and Byram (1968) to field capacity.

\begin{tabular}{|c|c|c|c|}
\hline Soil moisture drought index & SMDI & $\sum_{i=1}^{365}$ & $\begin{array}{l}\text { Hollinger et al. (1993) } \\
\text { as cited by Byun } \\
\text { and Wilhite (1999) }\end{array}$ \\
\hline Water stress coefficient & $\mathrm{K}_{\mathrm{s}}$ & $\begin{array}{l}\frac{S_{\mathrm{tot}}-S_{\mathrm{depl}}}{(1-p) \times S_{\mathrm{tot}}} \\
S_{\mathrm{tot}} \text { is total available soil water in the root zone }(\mathrm{mm}) \text {, } \\
S_{\mathrm{depl}} \text { root zone depletion }(\mathrm{mm}) \text { and } p \text { part of total } \\
\text { available soil water in the root zone that a crop can ex- } \\
\text { tract from the root zone without suffering from water } \\
\text { stress. }\end{array}$ & Allen et al. (1998) \\
\hline $\begin{array}{l}\text { Temperature-vegetation dryness } \\
\text { index }\end{array}$ & TVDI & $\begin{array}{l}\text { Surface soil moisture availability based on an empiri- } \\
\text { cal parameterization of the relationship between NDVI } \\
\text { and land surface temperature (LST) derived from satel- } \\
\text { lite observations. }\end{array}$ & Sandholt et al. (2002) \\
\hline $\begin{array}{l}\text { Modified perpendicular } \\
\text { drought index }\end{array}$ & MPDI & $\begin{array}{l}\text { Soil moisture and vegetation status on the basis of } \\
\text { near-infrared and red spectral reflectance space. }\end{array}$ & Ghulam et al. $(2007 a, b)$ \\
\hline $\begin{array}{l}\text { Average green water } \\
\text { storage availability }\end{array}$ & Avg-GWS & $\begin{array}{l}\text { Long-term average number of months in which } \\
S>1 \mathrm{~mm} \mathrm{~m}^{-1} \text {. }\end{array}$ & Schuol et al. (2008) \\
\hline
\end{tabular}


Table A4. Agricultural suitability under rain-fed conditions.

\begin{tabular}{|c|c|c|c|}
\hline Name & Abbreviation & Formula/description & Reference \\
\hline $\begin{array}{l}\text { GAEZ crop-specific suitability } \\
\text { under rain-fed conditions }\end{array}$ & GAEZ & $\begin{array}{l}\text { Crop-specific suitability under rain-fed conditions is } \\
\text { based on estimates of agro-ecologically attainable } \\
\text { yields. First, agro-climatically attainable yields are } \\
\text { determined based on a water balance approach that } \\
\text { calculates } E_{\text {act }} \text { and additionally considers crop water } \\
\text { requirements and a crop's sensitivity to water stress } \\
\text { during the various stages of growth to calculate a } \\
\text { yield reduction factor due to water limitations. Sec- } \\
\text { ond, agro-climatically attainable yields are further re- } \\
\text { duced by agro-edaphic constraints. }\end{array}$ & IIASA/FAO (2012) \\
\hline $\begin{array}{l}\text { GLUES crop-specific suitabil- } \\
\text { ity under rain-fed conditions }\end{array}$ & GLUES & $\begin{array}{l}\text { Crop-specific suitability under rain-fed conditions is } \\
\text { based on a fuzzy logic approach with crop-specific } \\
\text { membership functions for climatic, soil and topo- } \\
\text { graphic conditions. Yield estimates are not provided } \\
\text { by the GLUES methodology. }\end{array}$ & Zabel et al. (2014) \\
\hline
\end{tabular}


Appendix B: Relative green water availability indicators

Relative green water availability indicators are included in Tables B1 to B4. The following are some often used symbols in this appendix: $E_{\text {pot }}$ is potential evaporation, $E_{\text {pot,ref }}$ potential evaporation of FAO reference crop, $P$ precipitation and NDVI normalized difference vegetation index. 
Table B1. Meteorological drought indicators based on precipitation only.

\begin{tabular}{|c|c|c|c|}
\hline Name & Abbreviation & Formula/description & Reference \\
\hline Days of rain & DoR & $\sum$ day $\left.\right|_{P<P_{\text {thres }}}$ & $\begin{array}{l}\text { Munger (1916); Kincer (1919); } \\
\text { Blumenstock (1942) }\end{array}$ \\
\hline $\begin{array}{l}\text { Percent of average } \\
\text { precipitation }\end{array}$ & PoAP & $\frac{P}{\bar{P}}$ & $\begin{array}{l}\text { Bates (1935); Hoyt (1936) as } \\
\text { cited by World Meteorological } \\
\text { Organization (1975) }\end{array}$ \\
\hline $\begin{array}{l}\text { Foley drought } \\
\text { index }\end{array}$ & FDI & $\begin{array}{l}\text { Cumulative deficiency (excess) of } P \text { in cer- } \\
\text { tain month (period) compared to the long- } \\
\text { term average } P \text { for that month (period), ex- } \\
\text { pressed in thousands of annual } P \text {. }\end{array}$ & $\begin{array}{l}\text { Foley (1957) as cited by World } \\
\text { Meteorological Organization } \\
\text { (1975) and Keyantash and } \\
\text { Dracup (2002) }\end{array}$ \\
\hline $\begin{array}{l}\text { Rainfall anomaly } \\
\text { index }\end{array}$ & RAI & $\begin{array}{l} \pm 3 \frac{P-\bar{P}}{P_{\text {ext }}}-\bar{P} \\
\overline{P_{\text {ext }}} \text { is average of the } 10 \text { most extreme pre- } \\
\text { cipitation amounts on record (largest for pos- } \\
\text { itive and smallest for negative anomalies). } \\
\text { Can be calculated on weekly, monthly or an- } \\
\text { nual timescale (Wanders et al., 2010). }\end{array}$ & $\begin{array}{l}\text { Van Rooy (1965) as cited by } \\
\text { Keyantash and Dracup (2002) }\end{array}$ \\
\hline Deciles & - & $\begin{array}{l}\text { In which decile of a long-term record of pre- } \\
\text { cipitation events a certain precipitation event } \\
\text { falls. }\end{array}$ & $\begin{array}{l}\text { Gibbs and Maher (1967) as cited } \\
\text { by Wilhite and Glantz (1985) }\end{array}$ \\
\hline $\begin{array}{l}\text { Bhalme and Mooley } \\
\text { drought index }\end{array}$ & BMDI & $\begin{array}{l}\text { The percentage departure of monthly rainfall } \\
\text { from the long-term mean weighted by the re- } \\
\text { ciprocal of the coefficient of variation. }\end{array}$ & Bhalme and Mooley (1980) \\
\hline $\begin{array}{l}\text { Standardized } \\
\text { precipitation index }\end{array}$ & SPI & $\begin{array}{l}\text { Precipitation deviation for a normally dis- } \\
\text { tributed probability density with a mean of } \\
\text { zero and standard deviation of } 1 .\end{array}$ & McKee et al. (1993) \\
\hline $\begin{array}{l}\text { National rainfall } \\
\text { index }\end{array}$ & NRI & $\begin{array}{l}\text { National average of annual precipitation } \\
\text { weighed according to the long-term average } \\
\text { precipitation of all individual stations in a } \\
\text { country. }\end{array}$ & Gommes and Petrassi (1994) \\
\hline $\begin{array}{l}\text { Effective drought } \\
\text { index }\end{array}$ & EDI & $\begin{array}{l}\text { Ratio of the difference between effective } \\
\text { precipitation }(E P \text {, calculated from equations } \\
\text { based on precipitation) and its 5-day-running } \\
\text { mean over the standard deviation of this dif- } \\
\text { ference. }\end{array}$ & Byun and Wilhite (1999) \\
\hline $\begin{array}{l}\text { Precipitation } \\
\text { condition index }\end{array}$ & PCI & $\begin{array}{l}\frac{P-P_{\min }}{P_{\max }-P_{\min }} \\
P \text { inputs refer to monthly amounts. }\end{array}$ & Du et al. (2013) \\
\hline
\end{tabular}


Table B2. Meteorological drought indicators based on precipitation and a measure of potential evaporation.

\begin{tabular}{|c|c|c|c|}
\hline Name & Abbreviation & Formula/description & Reference \\
\hline Palmer drought severity index & PDSI & $\begin{array}{l}\text { Accumulated weighted dif- } \\
\text { ferences between actual } \\
\text { precipitation and precipitation } \\
\text { requirement of evaporation } \\
\text { (Wilhite and Glantz, 1985). }\end{array}$ & Palmer (1965); Alley (1984) \\
\hline Reconnaissance drought index & RDI & $\begin{array}{l}\text { Standardized ratio of } P \text { to } \\
E_{\text {pot based on a log-normal }} \\
\text { distribution. }\end{array}$ & $\begin{array}{l}\text { Tsakiris and Vangelis (2005); } \\
\text { Tsakiris et al. (2007) }\end{array}$ \\
\hline $\begin{array}{l}\text { Standardized precipitation } \\
\text { evapotranspiration index }\end{array}$ & SPEI & $\begin{array}{l}\text { Standardized difference be- } \\
\text { tween } P \text { and } E_{\text {pot based on a }} \\
\text { log-logistic distribution. }\end{array}$ & Vicente-Serrano et al. (2009) \\
\hline Water surplus variability index & WSVI & $\begin{array}{l}\text { Standardized difference be- } \\
\text { tween } P \text { and } E_{\text {pot, ref based on }} \\
\text { a logistic distribution. }\end{array}$ & Gocic and Trajkovic (2014) \\
\hline
\end{tabular}

Table B3. Vegetation drought indicators.

\begin{tabular}{|c|c|c|c|}
\hline Name & Abbreviation & Formula/description & Reference \\
\hline $\begin{array}{l}\text { Normalized difference } \\
\text { vegetation index anomaly }\end{array}$ & NDVIA & NDVI $-\overline{\text { NDVI }}$ & $\begin{array}{l}\text { Tucker (1979); } \\
\text { Myneni et al. (1998) }\end{array}$ \\
\hline Vegetation condition index & VCI & $\begin{array}{l}\text { NDVI-NDVI }{ }_{\min } \\
\text { NDVI }_{\max }-\mathrm{NDVI}_{\min } \\
\text { NDVI }_{\min } \text { is multi-year minimum of } \\
\text { smoothed weekly NDVI and NDVI } \\
\text { multi-year maximum of smoothed weekly } \\
\text { NDVI }\end{array}$ & Kogan $(1990,1995)$ \\
\hline Vegetation health index & VHI & $\begin{array}{l}a \cdot \mathrm{VCI}+b \cdot \mathrm{TCI} \\
a \text { is coefficient quantifying share of VCI } \\
\text { contribution in the combined condition, } b \\
\text { coefficient quantifying share of TCI contri- } \\
\text { bution in the combined condition, TCI Tem- } \\
\text { perature Condition Index and VCI Vegeta- } \\
\text { tion Condition Index }\end{array}$ & Kogan (2001) \\
\hline Standardized vegetation index & SVI & $\begin{array}{l}\text { NDVI deviation for a normally distributed } \\
\text { probability density with a mean of zero and } \\
\text { standard deviation of } 1 .\end{array}$ & Peters et al. (2002) \\
\hline $\begin{array}{l}\text { Normalized difference water } \\
\text { index anomaly }\end{array}$ & NDWIA & $\begin{array}{l}\text { Adaptation of NDVI (Gao, 1996) compared } \\
\text { to its multi-year mean. }\end{array}$ & Gu et al. (2007) \\
\hline $\begin{array}{l}\text { Enhanced vegetation index } \\
\text { anomaly }\end{array}$ & EVIA & $\begin{array}{l}\text { EVI anomaly. EVI is an improvement over } \\
\text { NDVI, which keeps sensitivity over densely } \\
\text { vegetated areas (Huete et al., 1994). }\end{array}$ & Saleska et al. (2007) \\
\hline $\begin{array}{l}\text { Percent of average seasonal } \\
\text { greenness }\end{array}$ & PASG & $\begin{array}{l}\frac{\mathrm{SG}}{\overline{\mathrm{SG}}} \times 100 \% \\
\mathrm{SG} \text { is seasonal greenness, defined as ac- } \\
\text { cumulated NDVI above background NDVI } \\
\text { during a specified period. }\end{array}$ & Brown et al. (2008) \\
\hline
\end{tabular}


Table B4. Relative soil moisture availability indicators.

\begin{tabular}{|c|c|c|c|}
\hline Name & Abbreviation & Formula/description & Reference \\
\hline Soil water deficit & SD (\& SMDI) & $\begin{array}{l}\text { Difference between mean weekly and long- } \\
\text { term median } S \text {, divided by the difference be- } \\
\text { tween long-term minimum (maximum) and } \\
\text { median } S \text {. }\end{array}$ & $\begin{array}{l}\text { Narasimhan and } \\
\text { Srinivasan (2005) }\end{array}$ \\
\hline $\begin{array}{l}\text { Palmer Z-index (a.k.a. Palmer } \\
\text { moisture anomaly index) }\end{array}$ & PZI & $\begin{array}{l}\text { Moisture anomaly for the current period } \\
\text { from the climate-average moisture condi- } \\
\text { tions for that period. }\end{array}$ & Palmer (1965); Alley (1984) \\
\hline Soil moisture anomaly index & SMAI & $\begin{array}{l}\frac{\theta-\bar{\theta}}{\bar{\theta}} \times 100 \% \\
\theta \text { is volumetric soil moisture content }\end{array}$ & Bergman et al. (1989) \\
\hline
\end{tabular}


Author contributions. Conceived and designed the study: A. Y. Hoekstra, J. F. Schyns and M. J. Booij. Executed the study: J. F. Schyns. Wrote the paper: J. F. Schyns, A. Y. Hoekstra and M. J. Booij.

Acknowledgements. The present work was (partially) developed within the framework of the Panta Rhei Research Initiative of the International Association of Hydrological Sciences (IAHS) and has been made possible by grants from the Water Footprint Network and Deltares.

Edited by: N. Ursino

\section{References}

Allen, R. G., Pereira, L. S., Raes, D., and Smith, M.: Crop evapotranspiration: Guidelines for computing crop water requirements, FAO Irrigation and drainage paper 56, Food and Agriculture Organization of the United Nations, Rome, Italy, available at: http://www.fao.org/docrep/X0490E/X0490E00.htm, 1998.

Alley, W. M.: The Palmer Drought Severity Index - Limitations and Assumptions, J. Clim. Appl. Meteorol., 23, 1100-1109, doi:10.1175/1520-0450(1984)023<1100:tpdsil>2.0.CO;2, 1984.

American Meteorological Society: Drought: An Information Statement of the American Meteorological Society, American Meteorological Society, Boston, USA, 5 pp., 2013.

Anderson, M. C., Norman, J. M., Mecikalski, J. R., Otkin, J. A., and Kustas, W. P.: A climatological study of evapotranspiration and moisture stress across the continental United States based on thermal remote sensing: 2. Surface moisture climatology, J. Geophys. Res.-Atmos., 112, D10117, doi:10.1029/2006jd007507, $2007 \mathrm{a}$.

Anderson, M. C., Norman, J. M., Mecikalski, J. R., Otkin, J. A., and Kustas, W. P.: A climatological study of evapotranspiration and moisture stress across the continental United States based on thermal remote sensing: 1. Model formulation, J. Geophys. Res.Atmos., 112, D11112, doi:10.1029/2006jd007506, 2007b.

Bates, C. G.: Climatic characteristics of the Plains Region, in: Possibilities of Shelterbelt Planting in the Plains Region, edited by: Silcox, F. A., United States Government, Washington, D.C., USA, 83-110, 1935.

Baudron, F. and Giller, K. E.: Agriculture and nature: Trouble and strife?, Biol. Cons., 170, 232-245, doi:10.1016/j.biocon.2013.12.009, 2014.

Baumgärtner, S., Becker, C., Faber, M., and Manstetten, R.: Relative and absolute scarcity of nature: Assessing the roles of economics and ecology for biodiversity conservation, Ecol. Econ., 59, 487-498, doi:10.1016/j.ecolecon.2005.11.012, 2006.

Bergman, K. H., Sabol, P., and Miskus, D.: Experimental indices for monitoring global drought conditions, in: Proceedings of the 13th Annual Climate Diagnostics Workshop, Cambridge, MA, USA, 31 October-4 November 1988, 190-197, 1989.

Bhalme, H. N. and Mooley, D. A.: Large-Scale Droughts/Floods and Monsoon Circulation, Mon. Weather Rev., 108, 1197-1211, doi:10.1175/1520-0493(1980)108<1197:1sdamc >2.0.CO;2, 1980 .
Blumenstock, G.: Drought in the United States Analyzed by Means of the Theory of Probability, USDA Technical Bulletins, No. 819, USDA, Washington, D.C., USA, 63 pp., 1942.

Brooks, T. M.: Conservation: Mind the gaps, Nature, 516, 336-337, doi:10.1038/516336a, 2014.

Brown, J. F., Wardlow, B. D., Tadesse, T., Hayes, M. J., and Reed, B. C.: The Vegetation Drought Response Index (VegDRI): A new integrated approach for monitoring drought stress in vegetation, Gisci. Remote Sens., 45, 16-46, doi:10.2747/1548-1603.45.1.16, 2008.

Budyko, M. I.: The heat balance of the earth's surface, US Dept. of Commerce, Weather Bureau, Washington, D.C., USA, 259 pp., 1958.

Butchart, S. H. M., Clarke, M., Smith, R. J., Sykes, R. E., Scharlemann, J. P. W., Harfoot, M., Buchanan, G. M., Angulo, A., Balmford, A., Bertzky, B., Brooks, T. M., Carpenter, K. E., Comeros-Raynal, M. T., Cornell, J., Ficetola, G. F., Fishpool, L. D. C., Fuller, R. A., Geldmann, J., Harwell, H., Hilton-Taylor, C., Hoffmann, M., Joolia, A., Joppa, L., Kingston, N., May, I., Milam, A., Polidoro, B., Ralph, G., Richman, N., Rondinini, C., Segan, D. B., Skolnik, B., Spalding, M. D., Stuart, S. N., Symes, A., Taylor, J., Visconti, P., Watson, J. E. M., Wood, L., and Burgess, N. D.: Shortfalls and Solutions for Meeting National and Global Conservation Area Targets, Conserv. Lett., 8, 329-337, doi:10.1111/conl.12158, 2015.

Byun, H.-R. and Wilhite, D. A.: Objective Quantification of Drought Severity and Duration, J. Climate, 12, 2747-2756, doi:10.1175/1520-0442(1999)012<2747:OQODSA>2.0.CO;2, 1999.

Capot-Rey, R.: Une carte de l'indice d'aridité au Sahara français, Bulletin de l'Association de géographes français, 216-217, 7376, 1951.

Chukalla, A. D., Krol, M. S., and Hoekstra, A. Y.: Green and blue water footprint reduction in irrigated agriculture: effect of irrigation techniques, irrigation strategies and mulching, Hydrol. Earth Syst. Sci. Discuss., 12, 6945-6979, doi:10.5194/hessd-12-69452015, 2015.

de Martonne, E.: Nouvelle carte mondial de l'indice d'aridité, Ann. Geogr., 288, 241-250, 1942.

Du, L., Tian, Q., Yu, T., Meng, Q., Jancso, T., Udvardy, P., and Huang, Y.: A comprehensive drought monitoring method integrating MODIS and TRMM data, Int. J. Appl. Earth Obs. Geoinf., 23, 245-253, doi:10.1016/j.jag.2012.09.010, 2013.

Erb, K.-H., Haberl, H., Krausmann, F., Lauk, C., Plutzar, C., Steinberger, J. K., Müller, C., Bondeau, A., Waha, K., and Pollack, G.: Eating the Planet: Feeding and fuelling the world sustainably, fairly and humanely - a scoping study, Social Ecology Working Paper 116, Institute of Social Ecology, Vienna, 132 pp., 2009.

Falkenmark, M., Lundqvist, J., and Widstrand, C.: Macro-scale water scarcity requires micro-scale approaches - aspects of vulnerability in semi-arid development, Natural Resources Forum, 13, 258-267, 1989.

Falkenmark, M.: Land-water linkages: A synopsis. Land and water integration and river basin management, Food and Agriculture Organization of the United Nations, Rome, Italy, 15-16, 1995.

Falkenmark, M.: Freshwater as shared between society and ecosystems: from divided approaches to integrated challenges, Philos T. Roy. Soc. B, 358, 2037-2049, doi:10.1098/rstb.2003.1386, 2003. 
Falkenmark, M.: Growing water scarcity in agriculture: future challenge to global water security, Philos. T. Roy. Soc. A, 371, 20120410, doi:10.1098/rsta.2012.0410, 2013a.

Falkenmark, M.: Water security - the multiform water scarcity, in: Water Security: principles, perspectives and practices, edited by: Lankford, B. B., K., Zeiton, M., Conway, D., Earthscan, London, UK, 64-79, 2013b.

Falkenmark, M. and Rockström, J.: Balancing Water for Humans and Nature: The New Approach in Ecohydrology, Earthscan, London, UK, 247 pp., 2004.

Falkenmark, M. and Rockström, J.: The new blue and green water paradigm: Breaking new ground for water resources planning and management, J. Water Resour. Plan. Manage.-Asce, 132, 129-132, doi:10.1061/(asce)0733-9496(2006)132:3(129), 2006.

Falkenmark, M. and Rockström, J.: Building Water Resilience in the Face of Global Change: From a Blue-Only to a Green-Blue Water Approach to Land-Water Management, J. Water Resour. Plan. Manage.-Asce, 136, 606-610, 2010.

Falkenmark, M., Berntell, A., Jägerskog, A., Lundqvist, J., Matz, M., and Tropp, H.: On the Verge of a New Water Scarcity: A Call for Good Governance and Human Ingenuity, SIWI, Stockholm, Sweden, 19 pp., 2007.

FAO: Early agrometeorological crop yield assessment, FAO Plant production and protection paper 73, FAO, Rome, Italy, 150 pp., 1986.

FAO: Economic valuation of water resources in agriculture: From the sectoral to a functional perspective of natural resource management, FAO Water reports 27, Food and Agriculture Organization of the United Nations, Rome, Italy, 2004.

FAO: Coping with water scarcity: An action framework for agriculture and food security, FAO Water reports 38, Food and Agriculture Organization of the United Nations, Rome, Italy, 78 pp., 2012.

FAO AQUASTAT Glossary: http://www.fao.org/nr/water/aquastat/ data/glossary/search.html?lang=en (last access: 2 March 2015), 2015.

Gao, B.: NDWI - A normalized difference water index for remote sensing of vegetation liquid water from space, Remote Sens. Environ., 58, 257-266, doi:10.1016/S0034-4257(96)00067-3, 1996.

Gerten, D., Hoff, H., Bondeau, A., Lucht, W., Smith, P., and Zaehle, S.: Contemporary "green" water flows: Simulations with a dynamic global vegetation and water balance model, Phys. Chem. Earth, 30, 334-338, doi:10.1016/j.pce.2005.06.002, 2005.

Gerten, D., Schaphoff, S., and Lucht, W.: Potential future changes in water limitations of the terrestrial biosphere, Clim. Change, 80, 277-299, doi:10.1007/s10584-006-9104-8, 2007.

Gerten, D., Heinke, J., Hoff, H., Biemans, H., Fader, M., and Waha, K.: Global Water Availability and Requirements for Future Food Production, J. Hydrometeorol., 12, 885-899, doi:10.1175/2011jhm1328.1, 2011.

Ghulam, A., Qin, Q., Teyip, T., and Li, Z.-L.: Modified perpendicular drought index (MPDI): a real-time drought monitoring method, ISPRS J. Photogram. Remote Sens., 62, 150-164, doi:10.1016/j.isprsjprs.2007.03.002, 2007a.

Ghulam, A., Qin, Q., and Zhan, Z.: Designing of the perpendicular drought index, Environ Geol, 52, 1045-1052, doi:10.1007/s00254-006-0544-2, $2007 \mathrm{~b}$.
Gocic, M. and Trajkovic, S.: Drought Characterisation Based on Water Surplus Variability Index, Water Resour. Manage., 28, 3179-3191, doi:10.1007/s11269-014-0665-4, 2014.

Gommes, R. A. and Petrassi, F.: Rainfall Variability and Drought in Sub-Saharan Africa Since 1960, Agrometeorology series working paper 9, Food and Agriculture Organization of the United Nations, Rome, Italy, 100 pp., 1994.

Gordon, L. J., Finlayson, C. M., and Falkenmark, M.: Managing water in agriculture for food production and other ecosystem services, Agricult. Water Manage., 97, 512-519, doi:10.1016/j.agwat.2009.03.017, 2010.

Gorczynski, W.: The aridity coefficient and its application to California, Technical Report, Scripps Institution of Oceanography, University of California, La Jolla, USA, 7 pp., 1940.

Gu, Y., Brown, J. F., Verdin, J. P., and Wardlow, B.: A five-year analysis of MODIS NDVI and NDWI for grassland drought assessment over the central Great Plains of the United States, Geophys. Res. Lett., 34, L06407, doi:10.1029/2006GL029127, 2007.

Hanasaki, N., Inuzuka, T., Kanae, S., and Oki, T.: An estimation of global virtual water flow and sources of water withdrawal for major crops and livestock products using a global hydrological model, J. Hydrol., 384, 232-244, doi:10.1016/j.jhydrol.2009.09.028, 2010.

Hargreaves, G. H.: The evaluation of water deficiencies, Age of Changing Priorities for Land and Water, Spokane, USA, 26-28 September, 1972.

Hayes, M.: Drought Indices, Intermountain West Climate Summary, Western Water Assessment, Colorado, USA, 2-6, 2007.

Heim, R. R.: A review of twentieth-century drought indices used in the United States, B. Am. Meteorol. Soc., 83, 1149-1165, 2002.

Hejazi, M., Edmonds, J., Clarke, L., Kyle, P., Davies, E., Chaturvedi, V., Wise, M., Patel, P., Eom, J., Calvin, K., Moss, R., and Kim, S.: Long-term global water projections using six socioeconomic scenarios in an integrated assessment modeling framework, Technol. Forecast. Soc. Change, 81, 205-226, doi:10.1016/j.techfore.2013.05.006, 2014.

Hiler, E. A. and Clark, R. N.: Stress Day Index To Characterize Effects Of Water Stress On Crop Yields, Trans. Am. Soc. Agricult Eng., 14, 757-761, 1971.

Hoekstra, A. Y.: The water footprint of modern consumer society, Routledge, London, UK, 204 pp., 2013.

Hoekstra, A. Y. and Mekonnen, M. M.: The water footprint of humanity, P. Natl. Acad. Sci. USA, 109, 3232-3237, doi:10.1073/pnas.1109936109, 2012.

Hoekstra, A. Y., Chapagain, A. K., Aldaya, M. M., and Mekonnen, M. M.: The water footprint assessment manual: setting the global standard, Earthscan, London, 203 pp., 2011.

Hoekstra, A. Y., Mekonnen, M. M., Chapagain, A. K., Mathews, R. E., and Richter, B. D.: Global monthly water scarcity: blue water footprints versus blue water availability, Plos One, 7, e32688, doi:10.1371/journal.pone.0032688, 2012.

Holzworth, D. P., Huth, N. I., deVoil, P. G., Zurcher, E. J., Herrmann, N. I., McLean, G., Chenu, K., van Oosterom, E. J., Snow, V., Murphy, C., Moore, A. D., Brown, H., Whish, J. P. M., Verrall, S., Fainges, J., Bell, L. W., Peake, A. S., Poulton, P. L., Hochman, Z., Thorburn, P. J., Gaydon, D. S., Dalgliesh, N. P., Rodriguez, D., Cox, H., Chapman, S., Doherty, A., Teixeira, E., Sharp, J., Cichota, R., Vogeler, I., Li, F. Y., Wang, E., Hammer, G. L., Robertson, M. J., Dimes, J. P., Whitbread, A. M., Hunt, 
J., van Rees, H., McClelland, T., Carberry, P. S., Hargreaves, J. N. G., MacLeod, N., McDonald, C., Harsdorf, J., Wedgwood, S., and Keating, B. A.: APSIM - Evolution towards a new generation of agricultural systems simulation, Environ. Model. Softw., 62, 327-350, doi:10.1016/j.envsoft.2014.07.009, 2014.

Huete, A., Justice, C., and Liu, H.: Development of vegetation and soil indices for MODIS-EOS, Remote Sens. Environ., 49, 224 234, doi:10.1016/0034-4257(94)90018-3, 1994.

Hunt, E. D., Hubbard, K. G., Wilhite, D. A., Arkebauer, T. J., and Dutcher, A. L.: The development and evaluation of a soil moisture index, Int. J. Climatol., 29, 747-759, doi:10.1002/joc.1749, 2009.

IIASA/FAO: Global Agro-Ecological Zones (GAEZ v3.0), IIASA/FAO, Laxenburg, Austria/Rome, Italy, 179 pp., 2012.

IPCC: Summary for Policymakers, in: Climate Change 2013: The Physical Science Basis. Contribution of Working Group I to the Fifth Assessment Report of the Intergovernmental Panel on Climate Change, Stocker, T. F., Qin, D., Plattner, G.-K., Tignor, M., Allen, S. K., Boschung, J., Nauels, A., Xia, Y., Bex V., and Midgley, P. M., Cambridge University Press, Cambridge, UK and New York, NY, USA, 3-29, 2013.

Isard, S. A., Welford, M. R., and Hollinger, S. E.: A Simple Soil Moisture Index to Forecast Crop Yields, Phys. Geogr., 16, 524538, doi:10.1080/02723646.1995.10642569, 1995.

Jackson, R. D., Idso, S. B., Reginato, R. J., and Pinter, P. J.: Canopy Temperature as a Crop Water-Stress Indicator, Water Resour. Res., 17, 1133-1138, doi:10.1029/WR017i004p01133, 1981.

Jenny, H.: Factors of Soil Formation: A System of Quantitative Pedology, Dover Publication Inc., New York, 191 pp., 1994 (first published in 1941).

Jones, C. A., Dyke, P. T., Williams, J. R., Kiniry, J. R., Benson, V. W., and Griggs, R. H.: EPIC: An operational model for evaluation of agricultural sustainability, Agricult. Syst., 37, 341-350, doi:10.1016/0308-521X(91)90057-H, 1991.

Kallis, G.: Droughts, Ann. Rev. Environ. Resour., 33, 85-118, doi:10.1146/annurev.environ.33.081307.123117, 2008.

Karl, T. R.: The Sensitivity of the Palmer Drought Severity Index and Palmer's Z-Index to their Calibration Coefficients Including Potential Evapotranspiration, J. Clim. Appl. Meteorol., 25, 77-86, doi:10.1175/15200450(1986)025<0077:TSOTPD>2.0.CO;2, 1986.

Kastner, T., Rivas, M. J. I., Koch, W., and Nonhebel, S.: Global changes in diets and the consequences for land requirements for food, P. Natl. Acad. Sci., 109, 6868-6872, doi:10.1073/pnas.1117054109, 2012.

Keetch, J. J. and Byram, G. M.: A drought index for forest fire control, USDA Forest Service Research Paper SE-38, Southeastern Forest Experiment Station, Asheville, NC, USA, 33 pp., 1968.

Keyantash, J. and Dracup, J. A.: The Quantification of Drought: An Evaluation of Drought Indices, B. Am. Meteorol. Soc., 83, 1167-1180, doi:10.1175/15200477(2002)083<1191:TQODAE>2.3.CO;2, 2002.

Kincer, J. B.: The Seasonal Distribution of Precipitation and its Frequency and Intensity in The United States, Mon. Weather Rev., 47, 624-631, doi:10.1175/15200493(1919)47<624:TSDOPA>2.0.CO;2, 1919.

Kogan, F. N.: Remote-Sensing of Weather Impacts on Vegetation in Nonhomogeneous Areas, Int. J. Remote Sens., 11, 1405-1419, 1990.
Kogan, F. N.: Droughts of the late 1980s in the UnitedStates as derived from NOAA polar-orbiting satellite data, B. Am. Meteorol. Soc., 76, 655-668, doi:10.1175/15200477(1995)076<0655:dotlit>2.0.CO;2, 1995.

Kogan, F. N.: Operational Space Technology for Global Vegetation Assessment, B. Am. Meteorol. Soc., 82, 1949-1964, doi:10.1175/1520-0477(2001)082<1949:OSTFGV>2.3.CO;2, 2001.

Köppen, W.: Grundriss der Klimakunde: Zweite, verbesserte Auflage der Klimate der Erde, Walter de Gruyter \& Co, Berlin and Leipzig, Germany, 388 pp., 1931.

Kummu, M., Gerten, D., Heinke, J., Konzmann, M., and Varis, O.: Climate-driven interannual variability of water scarcity in food production potential: a global analysis, Hydrol. Earth Syst. Sci., 18, 447-461, doi:10.5194/hess-18-447-2014, 2014.

Lang, R.: Verwitterung und Bodenbildung als Einführung in die Bodenkunde, Schweizerbart Science Publishers, Stuttgart, Germany, 188 pp., 1920.

Liu, J., Zehnder, A. J. B., and Yang, H.: Global consumptive water use for crop production: The importance of green water and virtual water, Water Resour. Res., 45, W05428, doi:10.1029/2007wr006051, 2009.

Maracchi, G.: Agricultural Drought - A Practical Approach to Definition, Assessment and Mitigation Strategies, in: Drought and Drought Mitigation in Europe, edited by: Vogt, J., and Somma, F., Advances in Natural and Technological Hazards Research, Springer, Dordrecht, the Netherlands, 63-75, 2000.

Marcovitch, S.: The Measure of Droughtiness, Mon. Weather Rev., 58, p. 113, doi:10.1175/1520 0493(1930)58<113:TMOD>2.0.CO;2, 1930.

Marletto, V., Zinoni, F., Botarelli, L., and Alessandrini, C.: Studio dei fenomeni siccitosi in Emilia-Romagna con il modello di bilancio idrico CRITERIA, RIAM, 9, 32-33, 2005.

McCown, R. L., Hammer, G. L., Hargreaves, J. N. G., Holzworth, D., and Huth, N. I.: APSIM: an agricultural production system simulation model for operational research, Math. Comp. Simul., 39, 225-231, doi:10.1016/0378-4754(95)00063-2, 1995.

McGuire, J. K. and Palmer, W. C.: The 1957 Drought in the Eastern United States, Mon. Weather Rev., 85, 305-314, doi:10.1175/1520-0493(1957)085<0305:TDITEU>2.0.CO;2, 1957.

McKee, T. B., Doesken, N. J., and Kleist, J.: The relationship of drought frequency and duration to time scales, in: Proceedings of the 8th Conference on Applied Climatology, Anaheim, USA, 17-22 January 1993, 179-183, 1993.

McQuigg, J.: A Simple Index of Drought Conditions, Weatherwise, 7, 64-67, doi:10.1080/00431672.1954.9930323, 1954.

Meyer, S. J., Hubbard, K. G., and Wilhite, D. A.: A Crop-Specific Drought Index for Corn: 1. Model Development and Validation, Agron. J., 85, 388-395, 1993.

Middleton, N. J. and Thomas, D. S. G.: World Atlas of Desertification, Arnold, London, UK, 69 pp., 1992.

Middleton, N. J. and Thomas, D. S. G.: World Atlas of Desertification, second edition, Arnold, London, UK, 182 pp., 1997.

Millennium Ecosystem Assessment: Ecosystems and Human Wellbeing: Synthesis, World Resources Institute, Washington, D.C., USA, 137 pp., 2005.

Mishra, A. K. and Singh, V. P.: A review of drought concepts, J. Hydrol., 391, 204-216, doi:10.1016/j.jhydrol.2010.07.012, 2010. 
Molden, D.: Water for Food, Water for Life: A Comprehensive Assessment of Water Management In Agriculture, Earthscan/International Water Management Institute, London, UK/Colombo, Sri Lanka, 645 pp., 2007.

Montesino Pouzols, F., Toivonen, T., Di Minin, E., Kukkala, A. S., Kullberg, P., Kuustera, J., Lehtomaki, J., Tenkanen, H., Verburg, P. H., and Moilanen, A.: Global protected area expansion is compromised by projected land-use and parochialism, Nature, 516, 383-386, doi:10.1038/nature14032, 2014.

Moran, M. S., Clarke, T. R., Inoue, Y., and Vidal, A.: Estimating crop water-deficit using the relation between surface-air temperature and spectral vegetation index, Remote Sens. Environ., 49, 246-263, doi:10.1016/0034-4257(94)90020-5, 1994.

Mu, Q., Zhao, M., Kimball, J. S., McDowell, N. G., and Running, S. W.: A Remotely Sensed Global Terrestrial Drought Severity Index, B. Am. Meteorol. Soc., 94, 83-98, doi:10.1175/bams-d11-00213.1, 2013.

Munger, T. T.: Graphic method of representing and comparing drought intensities, Mon. Weather Rev., 44, 642-643, doi:10.1175/1520-0493(1916)44<642:GMORAC>2.0.CO;2, 1916.

Myneni, R. B., Tucker, C. J., Asrar, G., and Keeling, C. D.: Interannual variations in satellite-sensed vegetation index data from 1981 to 1991, J. Geophys. Res.-Atmos., 103, 6145-6160, doi:10.1029/97JD03603, 1998.

Narasimhan, B. and Srinivasan, R.: Development and evaluation of Soil Moisture Deficit Index (SMDI) and Evapotranspiration Deficit Index (ETDI) for agricultural drought monitoring, Agricult. Forest Meteorol., 133, 69-88, doi:10.1016/j.agrformet.2005.07.012, 2005.

Nunez, M., Pfister, S., Anton, A., Munoz, P., Hellweg, S., Koehler, A., and Rieradevall, J.: Assessing the Environmental Impact of Water Consumption by Energy Crops Grown in Spain, J. Indust. Ecol., 17, 90-102, doi:10.1111/j.1530-9290.2011.00449.x, 2013.

Odegard, I. Y. R. and van der Voet, E.: The future of food - Scenarios and the effect on natural resource use in agriculture in 2050, Ecol. Econom., 97, 51-59, doi:10.1016/j.ecolecon.2013.10.005, 2014.

Ohlsson, L.: Water conflicts and social resource scarcity, Phys. Chem. Earth B, 25, 213-220, 2000.

Oki, T. and Kanae, S.: Global hydrological cycles and world water resources, Science, 313, 1068-1072, doi:10.1126/science.1128845, 2006.

Palmer, W. C.: Meteorological drought, Research paper 45, US Department of Commerce, Washington, D.C., USA, 58 pp., 1965.

Palmer, W. C.: Keeping Track of Crop Moisture Conditions, Nationwide: The New Crop Moisture Index, Weatherwise, 21, 156-161, doi:10.1080/00431672.1968.9932814, 1968.

Peixoto, J. P. and Oort, A. H.: Physics of climate, American Institute of Physics, New York, USA, 520 pp., 1992.

Pereira, L. S., Cordery, I., and Iacovides, I.: Coping with water scarcity, Technical Documents in Hydrology, Report No. 58, UNESCO, Paris, France, 269 pp., 2002.

Perez-Mendoza, H. A., Jaime Zuniga-Vega, J., Zurita-Gutierrez, Y. H., Fornoni, J., Solano-Zavaleta, I., Hernandez-Rosas, A. L., and Molina-Moctezuma, A.: Demographic importance of the lifecycle components in sceloporus grammicus, Herpetologica, 69, 411-435, 2013.
Peters, A. J., Walter-Shea, E. A., Ji, L., Vina, A., Hayes, M., and Svoboda, M. D.: Drought monitoring with NDVI-based standardized vegetation index, Photogram. Eng. Rem. Sens., 68, 7175, 2002.

Pfister, S., Koehler, A., and Hellweg, S.: Assessing the Environmental Impacts of Freshwater Consumption in LCA, Environ. Sci. Technol., 43, 4098-4104, doi:10.1021/es802423e, 2009.

Rickard, D. S.: The occurrence of agricultural drought at Ashburton, New Zealand, New Zeal. J. Agricult. Res., 3, 431-441, doi:10.1080/00288233.1960.10426627, 1960.

Rijsberman, F. R.: Water scarcity: Fact or fiction?, Agricult. Water Manage., 80, 5-22, doi:10.1016/j.agwat.2005.07.001, 2006.

Rockstrom, J., Lannerstad, M., and Falkenmark, M.: Assessing the water challenge of a new green revolution in developing countries, P. Natl. Acad. Sci. USA, 104, 6253-6260, 2007.

Rockström, J.: On-farm green water estimates as a tool for increased food production in water scarce regions, Phys. Chem. Earth B, 24, 375-383, doi:10.1016/s1464-1909(99)00016-7, 1999.

Rockström, J.: Green water security for the food makers of tomorrow: windows of opportunity in drought-prone savannahs, Water Science and Technology, 43, 71-78, 2001.

Rockström, J. and Falkenmark, M.: Semiarid Crop Production from a Hydrological Perspective: Gap between Potential and Actual Yields, Crit. Rev. Plant Sci., 19, 319-346, doi:10.1080/07352680091139259, 2000.

Rockström, J., Gordon, L., Folke, C., Falkenmark, M., and Engwall, M.: Linkages among water vapor flows, food production, and terrestrial ecosystem services, Conserv. Ecol., 3, art. 5, 1999.

Rockström, J., Falkenmark, M., Karlberg, L., Hoff, H., Rost, S., and Gerten, D.: Future water availability for global food production: The potential of green water for increasing resilience to global change, Water Resour. Res., 45, doi:10.1029/2007wr006767, 2009.

Rodrigues, A. S. L., Akcakaya, H. R., Andelman, S. J., Bakarr, M. I., Boitani, L., Brooks, T. M., Chanson, J. S., Fishpool, L. D. C., Da Fonseca, G. A. B., Gaston, K. J., Hoffmann, M., Marquet, P. A., Pilgrim, J. D., Pressey, R. L., Schipper, J., Sechrest, W., Stuart, S. N., Underhill, L. G., Waller, R. W., Watts, M. E. J., and Yan, X.: Global gap analysis: Priority regions for expanding the global protected-area network, Bioscience, 54, 10921100, doi:10.1641/0006-3568(2004)054[1092:ggaprf]2.0.CO;2, 2004a.

Rodrigues, A. S. L., Andelman, S. J., Bakarr, M. I., Boitani, L., Brooks, T. M., Cowling, R. M., Fishpool, L. D. C., da Fonseca, G. A. B., Gaston, K. J., Hoffmann, M., Long, J. S., Marquet, P. A., Pilgrim, J. D., Pressey, R. L., Schipper, J., Sechrest, W., Stuart, S. N., Underhill, L. G., Waller, R. W., Watts, M. E. J., and Yan, X.: Effectiveness of the global protected area network in representing species diversity, Nature, 428, 640-643, 2004b.

Saleska, S. R., Didan, K., Huete, A. R., and da Rocha, H. R.: Amazon Forests Green-Up During 2005 Drought, Science, 318, p. 612, 2007.

Sandholt, I., Rasmussen, K., and Andersen, J.: A simple interpretation of the surface temperature/vegetation index space for assessment of surface moisture status, Remote Sens. Environ., 79, 213-224, doi:10.1016/S0034-4257(01)00274-7, 2002.

Savenije, H. H. G.: Water scarcity indicators; the deception of the numbers, Phys. Chem. Earth B, 25, 199-204, doi:10.1016/s14641909(00)00004-6, 2000. 
Savenije, H. H. G.: The importance of interception and why we should delete the term evapotranspiration from our vocabulary, Hydrological Processes, 18, 1507-1511, doi:10.1002/hyp.5563, 2004.

Schuol, J., Abbaspour, K. C., Yang, H., Srinivasan, R., and Zehnder, A. J. B.: Modeling blue and green water availability in Africa, Water Resour. Res., 44, W07406, doi:10.1029/2007wr006609, 2008.

Seckler, D., Barker, R., and Amarasinghe, U.: Water Scarcity in the Twenty-first Century, Int. J. Water Resour. Develop., 15, 29-42, doi:10.1080/07900629948916, 1999.

Shafer, B. A. and Dezman, L. E.: Development of a surface water supply index (SWSI) to assess the severity of drought conditions in snowpack runoff areas, in: Proceedings of the 50th Annual Western Snow Conference, Reno, Nevada, USA, 19-23 April 1982, 164-175, 1982.

Sivakumar, M. V. K.: Agricultural Drought - WMO Perspectives, in: Proceedings of the WMO/UNISDR Expert Group Meeting on Agricultural Drought Indices, Murcia, Spain, 2-4 June 2010, 22-34, 2011.

Sivakumar, M. V. K., Motha, R. P., Wilhite, D. A., and Wood, D. A. (Eds.): Agricultural Drought Indices, Proceedings of the WMO/UNISDR Expert Group Meeting on Agricultural Drought Indices, Murcia, Spain, 2-4 June 2010, AGM-11, WMO/TD No. 1572, WAOB-2011, World Meteorological Organization, Geneva, Switzerland, 197 pp., 2011.

Sly, W. K.: A Climatic Moisture Index for Land and Soil Classification in Canada, Canad. J. Soil Sci., 50, 291-301, doi:10.4141/cjss70-040, 1970.

Smakhtin, V., Revenga, C., and Döll, P.: A Pilot Global Assessment of Environmental Water Requirements and Scarcity, Water Int., 29, 307-317, doi:10.1080/02508060408691785, 2004.

Smakhtin, V. U.: Low flow hydrology: a review, J. Hydrol., 240, 147-186, doi:10.1016/S0022-1694(00)00340-1, 2001.

Stadler, S. J.: Aridity Indexes, in: Encyclopedia of world climatology, edited by: Oliver, J. E., Springer, Heidelberg, Germany, 8994, 2005.

Steduto, P., Hsiao, T. C., Raes, D., and Fereres, E.: AquaCropThe FAO Crop Model to Simulate Yield Response to Water: I. Concepts and Underlying Principles, Agron. J., 101, 426-437, doi:10.2134/agronj2008.0139s, 2009.

Stöckle, C. O., Donatelli, M., and Nelson, R.: CropSyst, a cropping systems simulation model, Eur. J. Agron., 18, 289-307, doi:10.1016/S1161-0301(02)00109-0, 2003.

Sullivan, C. A., Meigh, J. R., and Giacomello, A. M.: The Water Poverty Index: Development and application at the community scale, Natural Resour. Forum, 27, 189-199, doi:10.1111/14778947.00054, 2003.

Svoboda, M., LeComte, D., Hayes, M., Heim, R., Gleason, K., Angel, J., Rippey, B., Tinker, R., Palecki, M., Stooksbury, D., Miskus, D., and Stephens, S.: The drought monitor, B. Am. Meteorol. Soc., 83, 1181-1190, 2002.

Tate, E. L., and Gustard, A.: Drought Definition: A Hydrological Perspective, in: Drought and Drought Mitigation in Europe, edited by: Vogt, J., and Somma, F., Advances in Natural and Technological Hazards Research, Springer, Dordrecht, the Netherlands, 23-48, 2000.

Thornthwaite, C. W.: The climates of North America: according to a new classification, Geogr. Rev., 21, 633-655, 1931.
Thornthwaite, C. W.: An Approach Toward a Rational Classification of Climate, Geogr. Rev., 38, 55-94, 1948.

Transeau, E. N.: Forest Centers of Eastern America, The American Naturalist, 39, 875-889, doi:10.2307/2455267, 1905.

Tsakiris, G. and Vangelis, H.: Establishing a drought index incorporating evapotranspiration, Eur. Water, 9, 3-11, 2005.

Tsakiris, G., Pangalou, D., and Vangelis, H.: Regional Drought Assessment Based on the Reconnaissance Drought Index (RDI), Water Resour. Manage., 21, 821-833, doi:10.1007/s11269-0069105-4, 2007.

Tucker, C. J.: Red and photographic infrared linear combinations for monitoring vegetation, Remote Sens. Environ., 8, 127-150, doi:10.1016/0034-4257(79)90013-0, 1979.

UNESCO: Bioclimatic map of the Mediterranean zone: ecological study of the Mediterranean zone, explanatory notes, Arid Zone Research, 21, edited by: FAO, and UNESCO, UNESCO-FAO, Paris, France, 58 pp., 1963.

van Dam, J. C., Groenendijk, P., Hendriks, R. F. A., and Kroes, J. G.: Advances of modeling water flow in variably saturated soils with SWAP, Vadose Zone J., 7, 640-653, doi:10.2136/vzj2007.0060, 2008.

van Oel, P. R. and Hoekstra, A. Y.: Towards Quantification of the Water Footprint of Paper: A First Estimate of its Consumptive Component, Water Resour. Manage., 26, 733-749, doi:10.1007/s11269-011-9942-7, 2012.

Venter, O., Fuller, R. A., Segan, D. B., Carwardine, J., Brooks, T., Butchart, S. H. M., Di Marco, M., Iwamura, T., Joseph, L., O’Grady, D., Possingham, H. P., Rondinini, C., Smith, R. J., Venter, M., and Watson, J. E. M.: Targeting Global Protected Area Expansion for Imperiled Biodiversity, PLoS Biol, 12, e1001891, doi:10.1371/journal.pbio.1001891, 2014.

Verdin, J. and Klaver, R.: Grid-cell-based crop water accounting for the famine early warning system, Hydrol. Proc., 16, 1617-1630, doi:10.1002/hyp.1025, 2002.

Vicente-Serrano, S. M., Beguería, S., and López-Moreno, J. I.: A Multiscalar Drought Index Sensitive to Global Warming: The Standardized Precipitation Evapotranspiration Index, J. Climate, 23, 1696-1718, doi:10.1175/2009JCLI2909.1, 2009.

Vörösmarty, C. J., Green, P., Salisbury, J., and Lammers, R. B.: Global water resources: Vulnerability from climate change and population growth, Science, 289, 284-288, doi:10.1126/science.289.5477.284, 2000.

Vörösmarty, C. J., Douglas, E. M., Green, P. A., and Revenga, C.: Geospatial Indicators of Emerging Water Stress: An Application to Africa, Ambio, 34, 230-236, doi:10.2307/4315590, 2005.

Vörösmarty, C. J., McIntyre, P. B., Gessner, M. O., Dudgeon, D., Prusevich, A., Green, P., Glidden, S., Bunn, S. E., Sullivan, C. A., Liermann, C. R., and Davies, P. M.: Global threats to human water security and river biodiversity, Nature, 467, 555-561, doi:10.1038/nature09440, 2010.

Wada, Y.: Human and climate impacts on global water resources, $\mathrm{PhD}$, Department of Physical Geography, Utrecht University, Utrecht, the Netherlands, 470 pp., 2013.

Wada, Y., van Beek, L. P. H., Viviroli, D., Duerr, H. H., Weingartner, R., and Bierkens, M. F. P.: Global monthly water stress: 2. Water demand and severity of water stress, Water Resour. Res., 47, W07518, doi:10.1029/2010wr009792, 2011.

Wallén, C. C.: Aridity Definitions and Their Applicability, Geograf. Ann. A, 49, 367-384, doi:10.2307/520903, 1967. 
Walton, K.: The arid zones, Transaction Publishers, New Jersey, USA, 175 pp., 1969.

Wanders, N., van Lanen, H. A. J., and van Loon, A. F.: Indicators for drought characterization on a global scale, WATCH Technical Report No. 24, Wageningen University, Wageningen, the Netherlands, 54 pp., 2010.

Weiskel, P. K., Wolock, D. M., Zarriello, P. J., Vogel, R. M., Levin, S. B., and Lent, R. M.: Hydroclimatic regimes: a distributed water-balance framework for hydrologic assessment, classification, and management, Hydrol. Earth Syst. Sci., 18, 3855-3872, doi:10.5194/hess-18-3855-2014, 2014.

Wilhelmi, O. V. and Wilhite, D. A.: Assessing vulnerability to agricultural drought: A Nebraska case study, Nat. Hazards, 25, 3758, doi:10.1023/a:1013388814894, 2002.

Wilhelmi, O. V., Hubbard, K. G., and Wilhite, D. A.: Spatial representation of agroclimatology in a study of agricultural drought, Int. J. Climatol., 22, 1399-1414, doi:10.1002/joc.796, 2002.

Wilhite, D. A. and Glantz, M. H.: Understanding the Drought Phenomenon: The Role of Definitions, Water International, 10, 111120, doi:10.1080/02508068508686328, 1985.

Woli, P., Jones, J. W., Ingram, K. T., and Fraisse, C. W.: Agricultural Reference Index for Drought (ARID), Agron. J., 104, 287-300, doi:10.2134/agronj2011.0286, 2012.
World Meteorological Organization: Drought and Agriculture: Report of the CAgM Working Group on the Assessment of Drought, Technical Note No. 138, Geneva, Switzerland, 127 pp., 1975.

Wu, H., Hubbard, K. G., and Wilhite, D. A.: An agricultural drought risk-assessment model for corn and soybeans, Int. J. Climatol., 24, 723-741, doi:10.1002/joc.1028, 2004.

WWAP: The United Nations World Water Development Report 2014: Water and Energy, UNESCO, Paris, France, 133 pp., 2014.

WWAP: The United Nations World Water Development Report 2015: Water for a Sustainable World, UNESCO, Paris, France, 122 pp., 2015.

Yao, Y., Liang, S., Qin, Q., and Wang, K.: Monitoring Drought over the Conterminous United States Using MODIS and NCEP Reanalysis-2 Data, J. Appl. Meteorol. Climatol., 49, 1665-1680, doi:10.1175/2010jamc2328.1, 2010.

Zabel, F., Putzenlechner, B., and Mauser, W.: Global Agricultural Land Resources - A High Resolution Suitability Evaluation and Its Perspectives until 2100 under Climate Change Conditions, PLoS ONE, 9, e107522, doi:10.1371/journal.pone.0107522, 2014. 